\title{
21 YEARS OF RESPONSIBLE INVESTING IN SOUTH AFRICA: KEY INVESTMENT STRATEGIES AND CRITERIA
}

\author{
Suzette Viviers \\ Stellenbosch University \\ sviviers@sun.ac.za
}

Received: June 2013

Accepted: April 2014

\begin{abstract}
The year 2013 marked the $21^{\text {st }}$ anniversary of responsible investing (RI) in South Africa. No systematic analysis of the nature of RI strategies and criteria has, however, been conducted. Content analysis of the investment mandates of $73 \mathrm{RI}$ funds has revealed that the majority of asset managers employ impact investing strategies which address social issues such as infrastructure development and economic empowerment. Semi-structured interviews with eight experts in the RI field have highlighted growing interest in impact investing and screening strategies. If $\mathrm{RI}$ in South Africa is to reach its full potential, then a broader range of investment strategies and criteria needs to be adopted. Asset managers can capitalise on gaps in the current RI offering by creating RI-orientated property funds, dedicated green funds, and funds which employ a best-in-sector screening strategy. A clear need for focused RI research, training and education in South Africa has furthermore been identified.
\end{abstract}

Keywords

Responsible investing, screening, shareholder activism, impact investing, environmental criteria, social criteria, corporate governance criteria

Prof S Viviers is Professor in the Department of Business Management, Stellenbosch University, South Africa. 


\section{INTRODUCTION}

Twenty-one years have passed since the launch of the first responsible investment (RI) fund in South Africa in 1992. On the one hand, RI allows investors to invest according to the tenets of their faith, in which case reference is made to ethical investing (Capelle-Blancard \& Monjon, 2012:243; Schwartz, Tamari \& Schwab, 2007:137). On the other hand, RI gives investors an opportunity to influence corporate policies and practices, and make a direct impact on the wellbeing of a particular community or society (Gifford, 2010:79; Neubaum \& Zahra, 2006:108).

Investors' motives for engaging in RI can originate either from a self-referential framework or from a comprehensive ethical framework (Sparkes \& Cowton, 2004:46). Investors employing a self-referential framework take a stand on what they do not want to own. As such, they refrain from investing in companies producing 'undesirable' products or services (such as alcohol, tobacco, gambling and pornography), companies operating in 'undesirable' industries (such as nuclear energy and defence) and 'undesirable' countries (such as South Africa pre-1994).

In contrast, investors who base their decisions on a comprehensive ethical framework prefer moral effectiveness to moral purity. Their decisions are typically motivated by a desire to improve ethics and corporate social responsibility within the companies in which they invest (henceforth called 'investee' companies). In this context, corporate responsibility refers to "the obligation of organisations to be accountable for their environment and for their stakeholders in a manner that goes beyond mere financial aspects" (Van Beurden \& Gössling, 2008:408). Investors who seek to support social entrepreneurs and uplift local communities through impact investments also take a comprehensive view of investing rather than a self-referential view. Investors employing a comprehensive ethical framework could thus be described as transformation-orientated investors.

A wide range of RI strategies and criteria have been developed over the years to suit the needs of both self-referential and transformation-orientated investors in South Africa. No systematic analysis of the nature of these strategies and criteria has, however, been conducted. Given South Africa's unique history, socio-economic status and cultural diversity, it is expected that a multi-faceted approach to RI has been adopted by market participants.

The aim of this article is to critically reflect on the investment strategies and criteria that have been used by South African RI asset managers over the past 21 years. If RI in South Africa is to reach its full potential, then a broader range of investment strategies and criteria needs to be adopted.

The article contains four sections. The first section reviews the RI strategies and criteria available to responsible investors and prior research on the topic in South Africa. The subsequent sections outline the methods that have been used to collect and analyse data, and summarise the findings. Finally, a number of recommendations for broadening the scope of RI in South Africa are presented.

\section{LITERATURE REVIEW}

Although there is no generally accepted definition of $\mathrm{RI}$, the concept essentially refers to an intricate process of integrating personal values and environmental, social and corporate 
governance (ESG) considerations into investment decisions and ownership practices (Renneboog, Ter Horst \& Zhang, 2008:1723).

\subsection{RI strategies and criteria}

'Responsible investors' have three main strategies at their disposal, namely screening, shareholder activism and impact investing. Screening can be negative, positive or a combination of both.

\subsubsection{Screening}

Self-referential investors who treat RI as 'a matter of ethical necessity' (Richardson \& Cragg, 2010:27) typically employ negative (exclusionary) screens which are based on their religious convictions (Girard \& Hassan, 2008:113), or ones that address highly specialised issues such as uranium or animal rights (Renneboog et al., 2008:1728). An ethical case for a negative screening strategy follows from the prima facie argument that holding a share in a company suggests approval of its activities, and that approving an immoral action is immoral (Larmer, 1997:397). By owning a security and earning a return from it, a shareholder thus indicates some acquiescence or support for the activities of the company in question. Mills (1996:3) follows the same line of thought when stating that

the righteousness of any monetary return is conditional upon the absence of the exploitation
of customers, workers, creditors and suppliers.

Research indicates that the majority of institutional investors in the United States of America (USA) use negative screens, most of which deal with social issues such as diversity and human rights (Rakotamavo, 2011:93). Renneboog, Ter Horst and Zhang (2011:573) have found that $94 \%$ of RI funds in the USA use exclusionary screens, but note that most of these centre on tobacco, alcohol, gambling, weapons and pornography. In the past, several researchers claimed that too few responsible investors were present in markets to effect real change (Barnea, Heinkel \& Kraus, 2005:332; Teoh, Welch \& Wazzan, 1999:35), but more recent research by Derwall, Koedijk and Ter Horst (2011:2137) shows that self-referential investors now appear to be large enough in number and homogeneous enough in terms of investment criteria to affect the supply and demand (and hence the prices) of securities in the USA.

Not all self-referential investors are concerned about transformation. This point was vividly expressed by the dean of a Quaker college in his response to whether the shunning of weapon manufacturers by his college would stop the armaments build-up in the USA. His response was: "No. Our board is not out to change the world. We are only seeking a oneness between ourselves and our Lord" (Hamilton, Jo \& Statman, 1993:62). The dean's response clearly illustrates faithbased investors' preference for moral purity over moral effectiveness.

Responsible investors operating from a comprehensive ethical framework may also employ positive or best-in-sector screening strategies. Positive screening involves the active search for and investment in companies that are perceived to be 'good corporate citizens' (Derwall et al., 2011:2137). Although no clear definition of a good corporate citizen exists, these companies typically have a public-concern focus, strategise according to a medium or long-term time horizon, have qualitative objectives that are not readily quantifiable in monetary terms, and consider externalities (Ambachtsheer, Myllynen \& Nuzum, 2006:9). 
Heese (2005:729) points out that sustainability screens often reflect a bias towards developed countries, as these criteria are based on northern hemisphere standards. She adds that this bias exists despite the need for developing countries to ensure that their own growth is not compromised by environmentally reckless actions or restrictive agreements. An example is the banning of dichlorodiphenyltrichloroethane (DDT), a colourless contact insecticide which is toxic to humans and animals when swallowed or absorbed through the skin. DDT has been banned in the USA for most uses since 1972, but is critical in the fight against malaria, which affects millions of people, most of whom live in Sub-Saharan Africa (Sadasivaiah, Tozan \& Breman, 2007:249).

A best-in-sector screening strategy combines positive and negative screens on a sector basis (Bauer, 0tten \& Rad, 2006:3). Using such an approach implies that a full universe of companies is evaluated against some key criterion, allowing investors to select the top-ranked company or companies across sectors, even though some might be deemed undesirable from a moral point of view (De Cleene \& Sonnenberg, 2002:17). A best-in-sector strategy is particularly suitable to developing countries which have a limited universe of listed securities (such as South Africa) (Baue, 2002).

\subsubsection{Shareholder activism}

Shareholder activism is a powerful mechanism for organisational change (Abegbite, Amaeshi \& Amao, 2012:389; Becht, Franks, Mayer \& Rossi, 2010:3093). Shareholder activism, also called 'active engagement', can be categorised as formal or informal. Formal activism refers to investors' actions that are taken in public, such as filing shareholder proposals, voting at annual general meetings and stimulating public debate (Nordén \& Strand, 2011:376). In contrast, informal shareholder activism entails private negotiations between asset managers and investee companies. Rehbein, Waddock and Graves (2006:239) have found that social activists in the USA are mainly religious groups, environmentalists and trade unions who target large, visible companies and focus on problematic products, environmental concerns and poor employee and community practices.

A growing body of knowledge suggests that institutional investors are increasingly voting with their shares and engaging in dialogue with investee companies (Gifford, 2010:79; Wen, 2009:308). Many researchers are, however, sceptical of the impact that shareholder activists are having on reforming corporate policies and practices (Sjöström, 2008:141; David, Bloom \& Hillman, 2007:91; Teoh et al., 1999:35). Evidence from a multi-country study reveals that the antecedents of shareholder activism vary according to the motivation of the activist (whether to improve financial performance or social performance), the nature of the firm based on size, ownership concentration and profitability, and the legal system of the country in which the investee company operates (Judge, Guar \& Muller-Kahle, 2010:258). Financial activism has been found to be stronger in common law countries, whereas social activism is more prominent in countries characterised by a high level of income inequality. Given South Africa's legal system and Gini coefficient, local companies are likely to experience high levels of both financial and social activism. This is sadly not the case (Crotty, 2012; Responsible investing - global trends and local experience, 2012:12; Planting 2011).

\subsubsection{Impact investing}

This RI strategy, which is most often used by transformation-orientated investors, is also referred to as 'community-based', 'cause-based' or 'targeted investing' (Eccles \& Viviers, 
2011:389; Needham, 2004). Responsible investors employing this strategy invest in real assets (such as infrastructure) that contribute to job creation and economic empowerment (Leeman, 2005:9). According to Weber (2010) and Sosa (2010), impact investments are a separate investment class for which there is a 'true moral hunger' among American investors. Insistence on social and/or environmental returns in addition to market-related financial returns distinguishes impact investments from conventional private equity (Jackson, 2012). Several role players in the South African RI market are of the opinion that impact investing is the most appropriate strategy to address the socio-economic challenges of the country (Opportunities for impact investing in South Africa, 2009:4).

As indicated in TABLE 1, RI represents a relatively small portion of the total assets under management in South Africa, with most of it taking the form of private equity.

\section{TABLE 1: Sustainable investment assets under management in South Africa on 31 December 2010 ( $\$$ billion $^{(a)}$}

\begin{tabular}{|c|c|c|c|c|c|}
\hline & $\begin{array}{l}\text { Total assets } \\
\text { under } \\
\text { management }\end{array}$ & $\begin{array}{l}\text { ESG- } \\
\text { integrated } \\
\text { strategy }^{(b)}\end{array}$ & $\begin{array}{c}\% \text { ESG- } \\
\text { integrated / } \\
\text { total assets } \\
\text { under } \\
\text { management }\end{array}$ & $\begin{array}{l}\text { ESG-branded } \\
\text { strategy }^{(c)}\end{array}$ & $\begin{array}{l}\text { \% ESG-branded / } \\
\text { total assets under } \\
\text { management }\end{array}$ \\
\hline $\begin{array}{l}\text { General } \\
\text { asset } \\
\text { management }\end{array}$ & 556.2 & 111.2 & $20.0 \%$ & 4.2 & $0.8 \%$ \\
\hline $\begin{array}{l}\text { Private } \\
\text { equity }\end{array}$ & 14.2 & 6.3 & $44.0 \%$ & 1.1 & $8 \%$ \\
\hline \multicolumn{6}{|c|}{$\begin{array}{l}\text { The authors preferred the term 'sustainable investment' to RI, and defined it as investments that integrate } \\
\text { ESG factors into analysis, stock selection and active ownership practices in the belief that these factors } \\
\text { can improve long-term risk management. } \\
\text { Defined as approaches that include ESG factors, but which may or may not brand themselves as } \\
\text { 'sustainable', 'responsible', 'impact' or 'green'. } \\
\text { Defined as approaches that are explicitly ESG-inclusive and marketed as such. }\end{array}$} \\
\hline
\end{tabular}

Source: Sinclair and Yao (2011)

Private equity investors are increasingly drawn to South Africa as a gateway to Africa, and tend to focus on material, social and environmental issues (Pickworth, 2012; Cranston, 2012; Swart, 2011).

\subsection{Prior research on RI strategies and criteria in South Africa}

In the first study of RI in South Africa, De Vries and De Villiers (1997:31) reported that very few unit trust managers considered non-financial criteria when evaluating investments. Those who did focused on the production of unhealthy/unsafe products (such as cigarettes, alcohol and weapons) and corporate policies and practices to control pollution, recycle resources and offer equal employment opportunities.

Ten years later Eccles, Nicholls and De Jongh (2007:15) evaluated the relative importance of ESG criteria among 32 local pension-fund principal officers, 19 asset managers and 11 advisory service providers. Participants viewed corporate governance, infrastructure development, 
employee relations, broad-based black economic empowerment (B-BBEE) and gender empowerment as the most important ESG considerations in South Africa. The emphasis on corporate governance is probably due to the publication of the three King reports on corporate governance in South Africa in 1994, 2002 and 2009. Considerably less attention was given to criteria relating to environmental management and climate change, a finding which was confirmed by Giamporcaro and Pretorius (2012:1), who argued that environmental issues are only likely to gain prominence once the more immediate developmental challenges facing the country have been addressed.

Members of South African pension/provident funds rank labour-related criteria such as health and safety, training and development and relationships with trade unions as the most important ESG screens (Viviers, Krüger \& Venter, 2012:125). Given South Africa's unique socio-political history and status as an emerging market, it is anticipated that social screens will feature prominently in the investment mandates of local RI funds.

\section{RESEARCH METHODOLOGY}

In the present study a mixed methods approach has been employed to collect and analyse qualitative data on the investment strategies and criteria that have been used by South African $\mathrm{Rl}$ asset managers over the past 21 years. An in-depth literature review was carried out by means of a comprehensive database of local RI funds, featuring each fund's name, asset manager, status (active versus discontinued), date of inception, date of discontinuance (where applicable), type (unitised versus non-unitised funds) and investment mandate. Data was sourced from RI fund fact sheets, asset manager websites and newspaper articles.

To clarify: active RI funds were defined as RI funds which had been launched on or after 1 June 1992 and which were still operational on 31 December 2012. Discontinued RI funds were defined as those RI funds which were established on or after 1 June 1992, but which were either closed or had merged with another fund at some point before 31 December 2012. This discontinued category also included RI funds whose investment mandates had changed to such an extent that they could no longer be classified as RI. 'Unitised funds' are funds where the asset manager pools the funds of many investors and spreads them across various asset classes. These funds are characterised by multi-client arrangements where the assets are owned by the manager, and participatory interests are allocated to the respective clients/investors (Hirt, Block \& Basu, 2006:44). Non-unitised funds, also called 'segregated funds', are characterised by an agreement between the asset manager and his/her client, whereby the client specifies certain investment criteria to which the asset manager is supposed to adhere. Segregated funds are designed with a particular client's needs and risk profile in mind and are thus well suited to the needs of responsible investors.

As indicated in FIGURE 1, the first two RI funds in South Africa were launched in 1992. Since then a further $71 \mathrm{RI}$ funds have been established. 


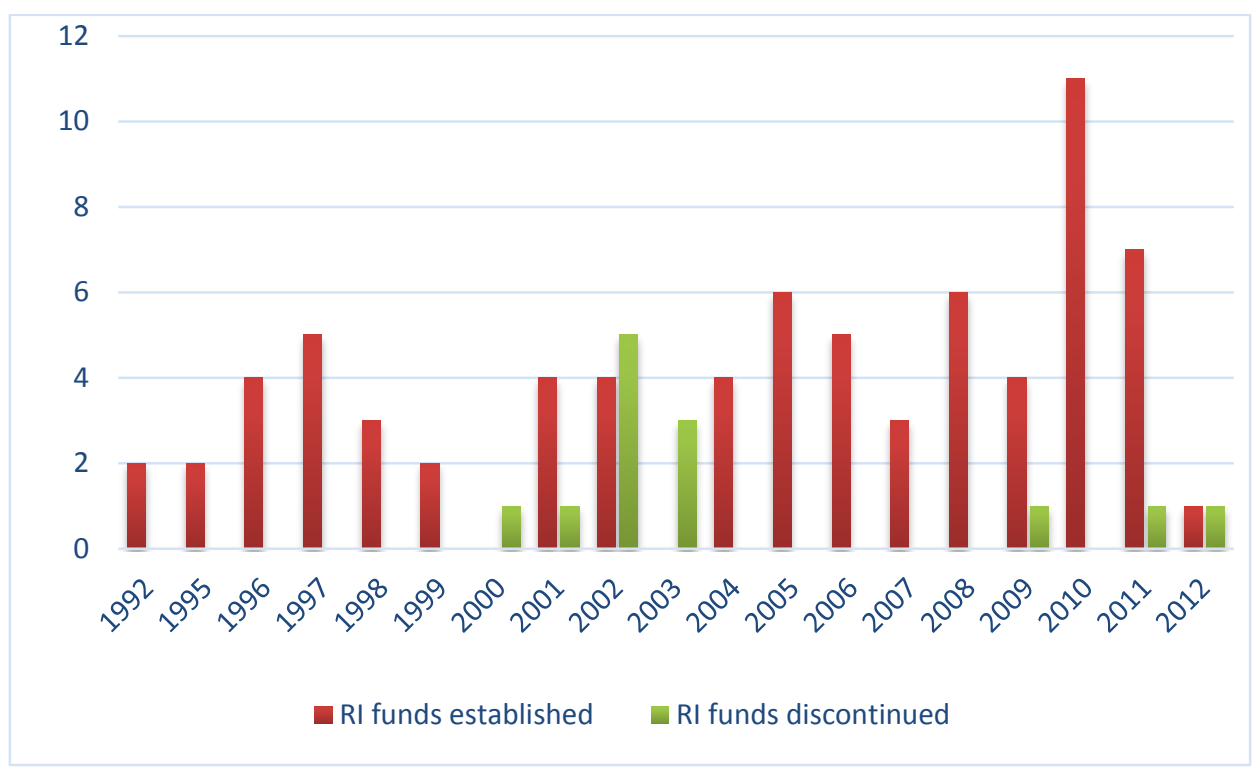

FIGURE 1: RI funds established and discontinued in South Africa over the period 1 June 1992 31 December 2012

Source: $\quad$ Author's compilation

The Asian financial crisis, which began in July 1997, had a profoundly negative impact on the fledgling RI market in South Africa. The contagion effect spilled over into South Africa in May 1998 when foreign asset managers began withdrawing their investments from all emerging markets, not only those in East Asia. Given the adverse consequences of the crisis and the subsequent poor performance of listed equities, many market participants became reluctant to invest in local RI funds (De Cleene \& Sonnenberg, 2004:4). Investors were particularly wary of funds facilitating empowerment transactions, because the special purpose vehicles created for this purpose proved unsustainable in the aftermath of the crisis (Hirsch, 2005; Thomas, 2004; Bridge, 1999). As indicated in FIGURE 1 , ten RI funds were discontinued over the period 2000 2003.

The $60 \mathrm{RI}$ funds which were active at the end of 2012 were managed by 24 asset managers of varying sizes. Futuregrowth Asset Managers, Old Mutual Investment Group South Africa (OMIGSA), Element Investment Managers and Oasis Crescent Management Group managed the majority of active RI funds in the country. The statistics in TABLE 2 indicate that active RI funds invested across all the major asset classes in South Africa. 
Viviers

TABLE 2: Spread of active RI funds across asset classes 1 June 1992-31 December 2012

\begin{tabular}{lcc}
\hline Asset class & $N$ & $\%$ \\
\hline Equity $^{(\mathrm{a})}$ & 20 & 33.3 \\
Asset allocation $^{(\mathrm{b})}$ & 16 & 26.7 \\
Fixed interest $^{(\mathrm{c})}$ & 6 & 10.0 \\
Alternative $^{(\mathrm{d})}$ & 17 & 28.3 \\
Property $^{(\mathrm{e})}$ & 1 & 1.7 \\
Total & 60 & 100.0
\end{tabular}

(a) A fund that invests predominantly in shares listed on the JSE. The asset manager invests a minimum of $75 \%$ of the market value of the fund in equities at all times and generally seeks maximum capital appreciation as the primary goal. All equity and derivative investments must conform $100 \%$ to the defined investment requirement of each category. However, a minimum of $80 \%$ of the equity portfolio must, at all times, be invested in the JSE sector(s) as defined by the category, and a maximum of $20 \%$ of the equity portfolio may be invested outside the defined JSE sector(s) provided that these investments comply fully with the category definition.

(b) A fund that invests in a wide spread of investments in the equity, bond, money and property markets.

(c) A fund that invests in bonds, money market investments and other income-earning securities.

(d) A fund that generally invests in unlisted securities and private equity initiatives by means of equity (including preference shares), debt or a combination thereof.

(e) A fund that invests in listed property shares, collective investment schemes in property, and property loan stock. The objective of a property fund is to provide high levels of income and long-term capital appreciation. Due to liquidity constraints in the real estate sector on the exchange these portfolios must maintain a minimum effective exposure to real estate securities of $50 \%$ and may include other highyielding fixed interest and other securities from time to time.

Source: Authors' compilation based on Classification of South African regulated collective investment portfolios (2012)

Quantitative content analysis was used to identify the RI strategies and criteria used by South African RI asset managers over the research period (1 June 1992 to 31 December 2012). Keywords and phrases such as 'avoid', 'exclude', 'Shari'ah-compliant' and 'Islamic lawcompliant' were seen as proxies for a negative screening strategy. Given the subjective nature of positive screens, various phrases were taken as indicative of a positive screening strategy. Some of these included 'to invest in companies involved in the reconstruction, development and empowerment of the South African labour force' and 'to invest in companies with good labour relations'. A shareholder activism strategy was characterised by phrases such as 'actively engage', 'constructive engagement' and 'the fund uses its presence to promote an awareness of corporate responsibility'. Finally, phrases such as 'targeting areas of social needs' and 'uplifting previously disadvantaged individuals through infrastructure development' were seen as indicative of an impact-investing strategy. Basic descriptive statistics were calculated once the data was coded.

Semi-structured interviews were conducted to gauge the views of a sample of local experts on future developments in the RI market. Participants were purposively selected based on their involvement in and knowledge of the RI market in South Africa. The sample consisted of five RI asset managers, two academics, a project manager of a national RI training programme, and a prominent shareholder activist. 


\section{RESULTS AND DISCUSSION}

A breakdown of the RI strategies and criteria used by South African RI asset managers over the past 21 years is presented in TABLES 3,4 and 5 .

TABLE 3: RI strategies used by South African RI asset managers over the period 1 June 199231 December 2012

\begin{tabular}{|c|c|c|c|c|c|c|}
\hline \multirow{2}{*}{ R/ strategy } & \multicolumn{2}{|c|}{ Active } & \multicolumn{3}{|c|}{ Discontinued } & \multirow{2}{*}{$\begin{array}{c}\text { Total } \\
\%\end{array}$} \\
\hline & $N$ & $\%$ & $N$ & $\%$ & $N$ & \\
\hline Negative screening & 17 & 28.3 & & & 17 & 23.3 \\
\hline Negative screening and shareholder activism & 1 & 1.7 & & & 1 & 1.4 \\
\hline Positive screening & 8 & 13.3 & 4 & 30.8 & 12 & 16.4 \\
\hline Positive screening and shareholder activism & 3 & 5.0 & & & 3 & 4.1 \\
\hline $\begin{array}{l}\text { Positive screening, shareholder activism and } \\
\text { impact investing }\end{array}$ & 1 & 1.7 & & & 1 & 1.4 \\
\hline $\begin{array}{l}\text { Positive screening, negative screening and } \\
\text { impact investing }\end{array}$ & 1 & 1.7 & 1 & 7.7 & 1 & 1.4 \\
\hline Shareholder activism & 3 & 5.0 & & & 3 & 4.1 \\
\hline Impact investing & 15 & 25.0 & 5 & 38.5 & 20 & 27.4 \\
\hline Impact investing and positive screening & 10 & 16.7 & 3 & 23.1 & 13 & 17.8 \\
\hline $\begin{array}{l}\text { Impact investing, positive screening and } \\
\text { shareholderactivism }\end{array}$ & 1 & 1.7 & & & 1 & 1.4 \\
\hline $\begin{array}{l}\text { Impact investing, negative screening and } \\
\text { shareholder activism }\end{array}$ & 1 & 1.7 & & & 1 & 1.4 \\
\hline Total & 60 & 100 & 13 & 100 & 73 & 100 \\
\hline $\begin{array}{l}\text { (a) Although this fund used both negative and po } \\
\text { best-in-sector screening approach. }\end{array}$ & e sc & , it doe & $\exp$ & ly stat & t it fo & \\
\hline
\end{tabular}

Source: Authors' compilation 
Viviers

TABLE 4: Investment criteria used by South Africa RI asset managers over the period 1 June 1992-31 December 2012

\begin{tabular}{|c|c|c|c|c|c|c|}
\hline \multirow{2}{*}{ Investment criteria } & \multicolumn{2}{|c|}{ Active } & \multicolumn{2}{|c|}{ Discontinued } & \multicolumn{2}{|c|}{ Total } \\
\hline & $N$ & $\%$ & $N$ & $\%$ & $N$ & $\%$ \\
\hline Ethical / Moral ${ }^{(a)}$ & 17 & 28.3 & & & 17 & 23.3 \\
\hline Environmental & 3 & 5.0 & & & 3 & 4.1 \\
\hline Social & 19 & 31.7 & 9 & 69.2 & 28 & 38.4 \\
\hline $\begin{array}{l}\text { Social } \\
\text { environmental }\end{array}$ & 7 & 11.7 & 3 & 23.1 & 10 & 13.7 \\
\hline $\begin{array}{l}\text { Social and corporate } \\
\text { governance }\end{array}$ & 2 & 3.3 & & & 2 & 2.7 \\
\hline$\varepsilon, S$ and $G^{(b)}$ & 11 & 18.3 & & & 11 & 15.1 \\
\hline Ethical, \&\& S & 1 & 1.7 & 1 & 7.7 & 2 & 2.7 \\
\hline Total & 60 & 100 & 13 & 100 & 73 & 100 \\
\hline \multicolumn{7}{|c|}{$\begin{array}{l}\text { (a) All of these criteria were based on Shari'ah (Islamic) law. Shari'ah is considered to be the infallible law of } \\
\text { God as opposed to the human interpretation of the law. Shari'ah investment criteria are based on a variety } \\
\text { of rules, including investing only in Shari'ah-compliant companies, appointing a Shari'ah board, carrying } \\
\text { out an annual Shari'ah audit and purifying certain prohibited types of income, such as interest, by } \\
\text { donating them to charity (Sharia, 2013; Shari'ah-compliant funds, 2013). }\end{array}$} \\
\hline \multicolumn{7}{|l|}{ (b) Includes funds tho } \\
\hline
\end{tabular}

Source: Authors' compilation

TABLE 5: RI strategies versus criteria

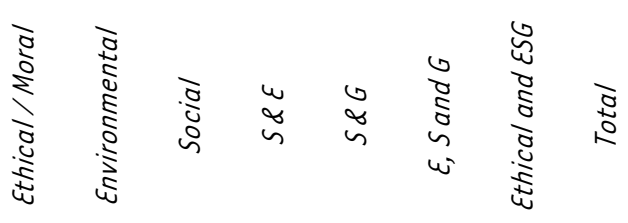

\begin{tabular}{|c|c|c|c|c|c|c|c|}
\hline Negative screening & 17 & & & & & & 17 \\
\hline Negative screening and shareholder activism & & & & & & 1 & 1 \\
\hline Positive screening & 2 & 4 & 3 & & 3 & & 12 \\
\hline Positive screening and shareholder activism & & & & 1 & 2 & & 3 \\
\hline $\begin{array}{l}\text { Positive screening, shareholder activism and } \\
\text { impact investing }\end{array}$ & & & & 1 & & & 1 \\
\hline $\begin{array}{l}\text { Positive screening, negative screening and } \\
\text { impact investing }\end{array}$ & & & & & & 1 & 1 \\
\hline Engagement & & & & & 3 & & 3 \\
\hline
\end{tabular}




\begin{tabular}{|c|c|c|c|c|c|c|c|c|}
\hline & $\begin{array}{l}\bar{d} \\
\vdots \\
\frac{1}{2} \\
\vdots \\
\frac{d}{d} \\
\frac{d}{w}\end{array}$ & 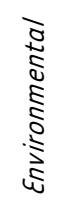 & $\frac{\grave{d}}{\grave{0}}$ & $\tilde{w}$ & $\underset{\omega}{\infty}$ & $\begin{array}{l}0 \\
0 \\
\delta \\
0 \\
w \\
w\end{array}$ & $\begin{array}{l}0 \\
\tilde{w} \\
0 \\
\delta \\
0 \\
0 \\
\frac{0}{5} \\
w\end{array}$ & 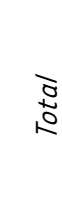 \\
\hline Impact investing & & 1 & 16 & 3 & & & & 20 \\
\hline Impact investing and positive screening & & & 8 & 3 & & 2 & & 13 \\
\hline $\begin{array}{l}\text { Impact investing, positive screening and } \\
\text { shareholderactivism }\end{array}$ & & & & 1 & & & & 1 \\
\hline $\begin{array}{l}\text { Impact investing, negative screening and } \\
\text { shareholderactivism }\end{array}$ & & & & & & 1 & & 1 \\
\hline Total & 17 & 3 & 28 & 10 & 2 & 11 & 2 & 73 \\
\hline
\end{tabular}

Source: Authors' compilation

The findings will be discussed from the perspective of self-referential and transformationorientated investors respectively.

\subsection{RI strategies and criteria used by self-referential investors}

As indicated earlier, faith-based investors mainly employ negative screening strategies to avoid morally unacceptable investments. As illustrated in TABLE 3, 20 local RI funds employed a negative screening strategy (either on its own or in combination with other RI strategies). Closer inspection of the investment mandates of these funds revealed that 17 funds employed negative screens based on Shari'ah principles (see TABLES 4 and 5). All 17 of these funds were active at the end of 2012. The prominence of Islamic funds in South Africa is in line with findings of Renneboog et al. (2011:573), who established that more than a third of RI funds in Africa and the Asia-Pacific Rim countries use Islamic screens.

Most of the South African Shari'ah-compliant funds (76.8\%) do not specify the investment criteria they use. Two funds use the Shari'ah principles underpinning the FTSE/JSE Shari'ah All Share and Top 40 indices, which were launched in South Africa in 2007 and 2008 (FTSE/JSE Africa Index Series-Specialist Indices-Shari'ah, 2013). More details on these two indices are presented in Appendix A. The ethical/moral criteria which are specifically mentioned include (listed in order of frequency): alcohol, gambling, tobacco, non-Halaal products, defence/weapons, interest-bearing instruments / conventional financial institutions, high levels of gearing, entertainment, and pornography.

One of the first RI funds launched in South Africa in 1992, the Old Mutual Albaraka Equity Fund, was a Shari'ah-compliant fund. These funds became attractive investment options in South Africa in the aftermath of the Asian market crisis (Cameron, 2003; Jenvey, 2003) and again after the 2008 global financial crisis (Albanese, 2012). Authors attributed the funds' sound postAsian market crisis performance to the fact that they excluded financial institutions and retailers, two sectors that were particularly hard hit by the crisis. Abdulla, Hassan and Mohamad (2007:142) also determined that Islamic unit trusts in Malaysia outperformed conventional funds during bearish economic trends. Research by Viviers and Firer (2013:217) has shown that 
Shari'ah-compliant funds in South Africa were among the top performing RI funds (based on risk adjusted performance) over the period October 2008 to August 2011.

Growth in Islam and Islamic financing is not unique to South Africa (Islamic Wealth Management Report, 2012:21). Although only approximately $2 \%$ of the South African population claim to be Muslim (International Religious Freedom Report 2005, 2005), support for Islam is rapidly growing, especially among black South Africans (Bell, 2004; Itano, 2002). The trend is ascribed to Islam's emphasis on charity, and the faith's focus on lifestyle and social reform.

A generational change is observed in that Shari'ah-compliant investing is gaining momentum among young professionals (Rise in Shari'ah compliance, 2012). A local asset manager remarked that not only are there only more Shari'ah-compliant investments available, but young professionals are also discovering the benefits of these diversified portfolio options. According to one of the largest asset managers in the country, the retirement industry is becoming a big contributor to the growth of local Shari'ah investments. In recent years the Oasis Group has launched several new Shari'ah-compliant funds, including portfolios focused on equities, property, income, life-staging asset allocation and balanced funds. In a special report on Islamic financing in South Africa, Patel (2012) remarks that the scope for Islamic financing is substantial as it can be used to "encourage small and medium-size enterprise development, provide affordable housing, finance infrastructure projects, facilitate black economic empowerment deals, etc. while always ensuring fair, ethical business practices aligned with an increase in real assets and employment." It thus seems that both financial and societal benefits can be derived through the adoption of a faith-based self-referential framework.

One of the participants in the study managed a Shari'ah-compliant fund and was of the opinion that more money would flow into these funds in future. Growth in faith-based funds in South Africa could also be attributed to the launch of the two FTSE/JSE Shari'ah indices. Elfakhani and Hassan (2005:3) claimed that the establishment of credible Shari'ah equity benchmarks, such as the Dow Jones Islamic Market Index, the FTSE Global Islamic Index Series and the Malaysian Kuala Lumpur Syariah Index, represented a turning point for the industry globally. They argued that these indices gave investors (both Islamic and conventional) a benchmark against which to compare their investments' performance.

Although several RI funds are available to Muslim investors in South Africa (both retail and institutional), the question remains whether these funds are suitable for investors from other religions. According to an Islamic Wealth Management Report (2012:21), non-Muslim investors are increasingly drawn to Shari'ah-compliant funds globally. Whether this will be the case in South Africa remains to be seen.

The influence of the Christian faith in establishing and growing the RI movement globally is quite significant. In the 1970s and 1980s, religious organisations in the USA spearheaded the antiSouth Africa divestment campaigns, and still command considerable assets and influence (Williams, 2007:43). According to Richardson and Cragg (2010:27) and Proffitt and Spicer (2006:165), churches continue to be the vanguard of change in the USA and now concern themselves with issues pertaining to climate change and environmental justice. Given that Christianity has the largest following of all religions in South Africa, it is surprising that local churches have not embraced RI as a means of promoting organisational and societal change (be it in terms of screening or shareholder activism strategies). A collective Christian voice could serve as a powerful mechanism for organisational and societal change in the country. 


\subsection{RI strategies and criteria used by transformation-orientated investors}

The statistics in TABLES 3, 4 and 5 show that several RI funds are available to transformationorientated RI investors in South Africa. As indicated earlier, these investors could pursue positive screening, best-in-sector screening and shareholder activism, and/or impact investing strategies.

\subsubsection{RI strategies}

Almost half of all active RI funds in South Africa (48.5\%) employ an impact investing strategy (either on its own or in combination with other strategies, mostly positive screening). This can be ascribed to South Africa's unique history, and may reflect a genuine desire (moral hunger) among local asset owners and managers to address the imbalances of the past and contribute to sustainable socio-economic growth in the country. The fact that most of the discontinued RI funds followed an impact investing strategy reflects the complexity of these funds.

All of the interviewees in the study indicated that impact investing is likely to increase in South Africa in the next five to 10 years. They attributed this to growing international interest in private equity and regulatory changes which place a renewed emphasis on economic empowerment and enterprise development.

Only three local RI funds use shareholder activism as their primary RI strategy, while another seven RI funds combine shareholder activism with another strategy (mostly positive screening). It was not possible from the content analysis to determine the nature of activism (formal or informal) practised by the relevant fund managers. An analysis of the websites of the 28 asset managers who were signatories of the United Nations Principles for Responsible Investing (UNPRI) at the end of 2012 reveals that only six asset managers published their proxy voting policies and records online. This finding on formal shareholder activism in South Africa is in line with Winfield (2011:3), who suggests that very few asset managers in South Africa are "excited, passionate or serious" about proxy voting.

In response to the call for heightened (formal) shareholder activism in the second King report on corporate governance in South Africa, Rademeyer and Holtzhausen (2004:767) examined this RI strategy from a legal perspective. They cautioned that any attempts to promote shareholder activism in South Africa should address the real reasons that underpin shareholder apathy. These included a lack of access to company information, a lack of expertise and knowledge to process this information, a lack of recognition of the importance of shareholder activism, the disparity between the high costs involved in taking shareholder activism seriously, and the small size of many shareholders' stakes in investee companies. Unfortunately, many of these factors still impede formal shareholder activism in South Africa.

Feedback from the semi-structured interviews suggests that shareholder activism in South Africa mainly takes the form of private, informal negotiations. One participant explained that it "is not cost-effective for anyone to be a leader in a (formal) activist charge as support may be moral, but not financial ... Activism in South Africa is more likely to be driven by shame - as when something really offensive appears in the press." The participant acknowledged that although shame might provoke some response from investors, it is more prevalent in the USA than in South Africa. The impact of culture on the type of shareholder activism practised by shareholders in a particular country was also observed by Gifford (2010:80) and Poulsen, Strand 
and Thomsen (2010:330). According to the participants, most of the activism that does take place in South Africa takes the form of financial activism (on issues such as mergers and acquisitions and share option schemes) and not social activism. Some growth in informal activism is anticipated, as more South African asset owners and managers are becoming signatories of the UNPRI and the Code of Responsible Investment in South Africa launched by CRISA in 2011. More details on these two important drivers of RI are presented in Appendix A.

Not a single RI fund in South Africa employs a best-in-sector screening strategy. Not only is this finding surprising given the limited universe of listed securities on the JSE, but it is also disconcerting, because empirical findings suggest that this strategy could yield abnormally high returns even after taking transaction costs into account (Statman \& Glushkov, 2009:33; Kempf \& Osthoff, 2007:809).

\subsubsection{ESG criteria}

Although environmental criteria are mentioned in $26 \mathrm{RI}$ funds' investment mandates, closer investigation reveals that 18 of these funds (69\%) merely evaluate companies based on 'sound' environmental practices. Only four RI funds (all of which were launched in the last two years of this study) formulate detailed environmental criteria. These funds evaluate companies on carbon emissions, renewable energy, biodiversity, green building and construction and the development of agricultural land. Important events shaping the nature of environmental criteria are listed in Appendix A, the most important of which is the introduction of the Carbon Disclosure Project in South Africa in 2009.

A review of the RI literature in South Africa (Viviers et al., 2012:120; Eccles et al., 2007:15; De Cleene \& Sonnenberg, 2002:17) suggests that social criteria consist of the three sub-categories presented in TABLE 6 and FIGURE 2.

TABLE 6: Social criteria used by South African RI asset managers over the period 1 June 199231 December 2012

\begin{tabular}{|c|c|c|c|}
\hline Sub-category & $\begin{array}{c}\text { Criteria specifically mentioned in R/ funds' } \\
\text { investment mandates }\end{array}$ & $\begin{array}{c}\text { Number of } \\
\text { times } \\
\text { mentioned }\end{array}$ & Total \\
\hline \multirow{10}{*}{$\begin{array}{l}\text { Infrastructure } \\
\text { development }\end{array}$} & $\begin{array}{l}\text { Infrastructure in rural / previously disadvantaged / } \\
\text { under-serviced communities }\end{array}$ & 9 & \multirow{10}{*}{29} \\
\hline & Electricity / energy & 7 & \\
\hline & Water / dams & 5 & \\
\hline & Sanitation / sewerage & 5 & \\
\hline & Housing & 5 & \\
\hline & Health care facilities & 5 & \\
\hline & Roads / bridges & 5 & \\
\hline & Communication networks & 4 & \\
\hline & Schools / educational facilities & 4 & \\
\hline & Municipal services (e.g. waste management) & 3 & \\
\hline
\end{tabular}




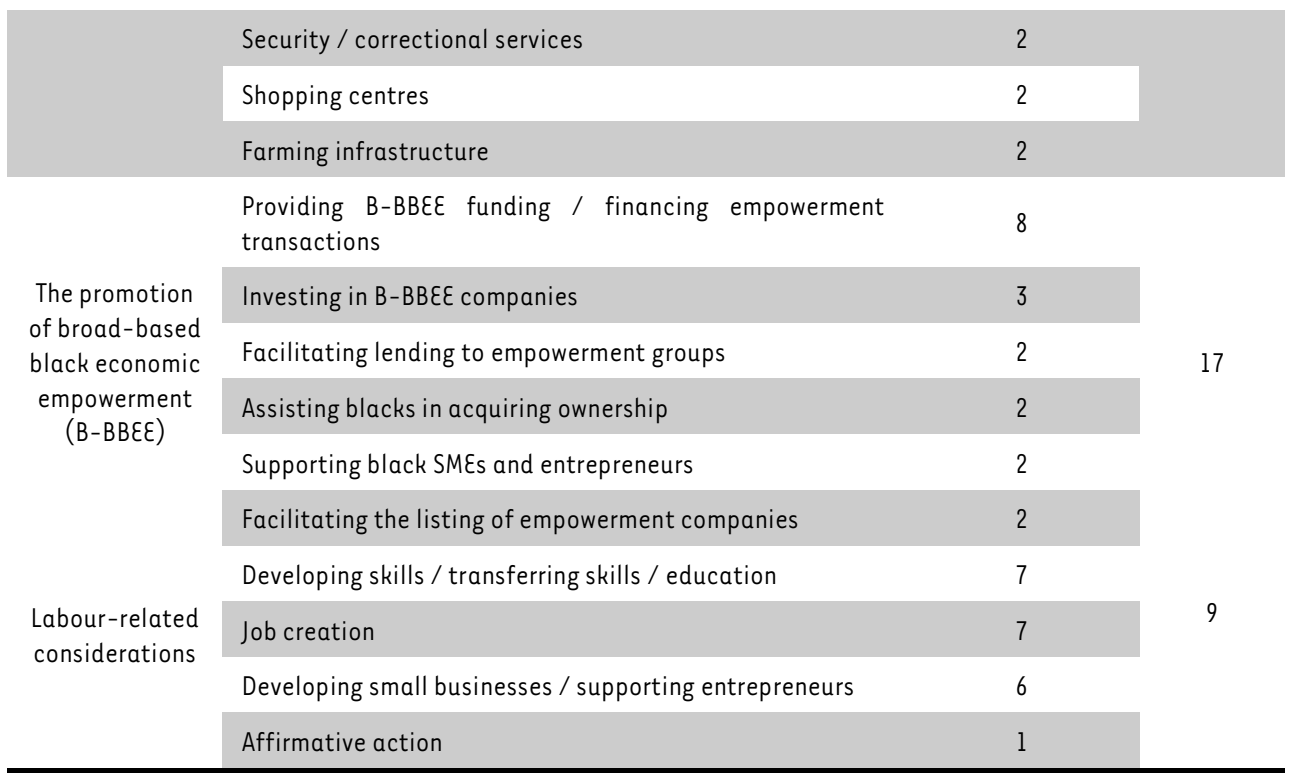

\section{Source: Authors' compilation}

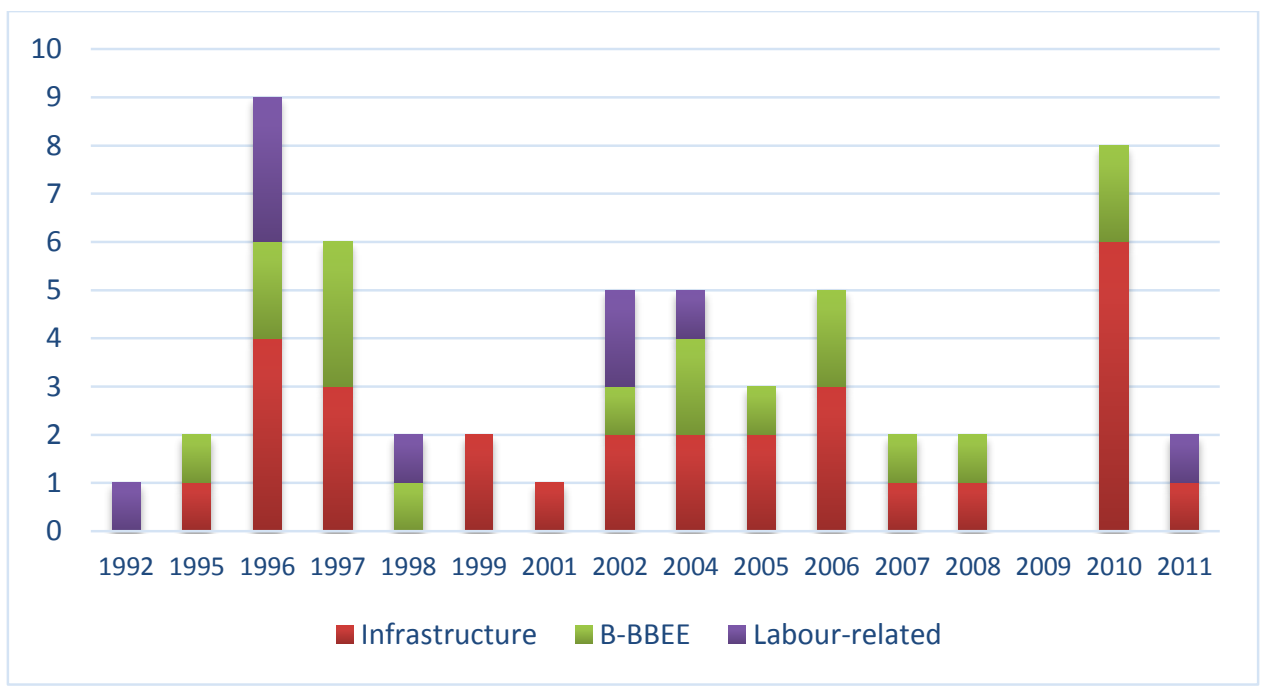

FIGURE 2: Social criteria employed by RI funds over the period 1 June 1992-31 December 2012

Source: $\quad$ Authors' compilation

Although infrastructure development is the most frequently mentioned social consideration, almost half of these funds do not specify the nature of the investments which they target. Many merely state that they support economic and social infrastructure development in rural areas, previously disadvantaged and/or under-serviced communities. Those RI funds that do make specific reference to the types of infrastructure projects they support focus on the provision of electricity/energy provision, water infrastructure, sanitation/sewerage, low income housing, health care, roads and bridges. 
With the exception of 1992, 1998, 2009 and 2012, new RI funds with an infrastructure focus were launched in South Africa every year over the past 21 years. Important events shaping the infrastructure agenda in South Africa are set out in Appendix A and include the launch of the Reconstruction and Development Programme in 1996, the Financial Sector Charter in 2004, the creation of the South African Network for Impact Investing in 2008 and the introduction of the government's New Growth Path in 2009.

The second-largest category of social criteria deals with the promotion of B-BBEE. Given the absence of a clear definition of empowerment, many of the early RI funds do not specify the criteria used. However, after the promulgation of the B-BBEE Act (No. 53 of 2003), asset owners and managers were in a better position to formulate specific criteria on this uniquely South African issue. The great majority of RI funds which aim to promote empowerment in South Africa are classified as impact investments, and provide financing to designated groups and companies.

One of the first RI funds to be launched in South Africa, the Community Growth Equity Fund, introduced the use of labour-related screens. The fund is managed by the Community Growth Management Company, which is jointly owned by Unity Incorporation (representing a group of seven trade unions) and OMIGSA. The fund was established as a result of local trade unions' refusal to invest their members' funds in companies that were supportive of the apartheid regime or those that practised poor industrial relations. Most of the other RI funds employing labour-related criteria were established in the first decade of democracy. The promulgation of the Employment Equity Act (No. 55 of 1998) and the Skills Development Act (No. 97 of 1998) strongly contributed to an understanding of labour-related issues in South Africa. The emphasis on social criteria by local RI fund managers is in line with prior research internationally and in South Africa (Renneboog et al., 2008:1733; Proffitt \& Spicer, 2006:165).

As indicated in TABLE 5, the combination of environmental and social criteria is popular among South African RI asset managers, and supports the idea that these issues are inextricably linked. Local asset owners and managers seem to realise that economic development should not come at the expense of the natural environment.

Contrary to expectation and prior research (Bhana, 2010:1; Eccles et al., 2007:3), corporate governance criteria have not featured prominently in local RI fund mandates. Corporate governance criteria were evaluated by only $18 \%$ of $\mathrm{Rl}$ asset managers. Not a single RI fund evaluates corporate governance disclosure or performance in isolation; it is always evaluated alongside social and environmental criteria.

Seven RI funds mimic the composition of the FTSE/JSE Socially Responsible Investment (SRI) index (TABLE 4). This index was the first of its kind in an emerging market and the first to be launched by a stock exchange (Wadula, 2004). The Johannesburg Securities Exchange (JSE) in consultation with an independent panel of experts including investment managers, listed companies, sustainability experts, academics and civil society, developed a range of ESG criteria in 2004 against which JSE-listed companies could be evaluated on an annual basis (FTSE/JSE SRI index, 2013). Fifty-one companies were included as constituents in the index in 2004, increasing to 77 in 2012 (representing $21 \%$ of all companies listed on the exchange). The advantage of mimicking an RI index is that it reduces the need for independent ESG research by the asset manager.

Other key events that have promoted the integration of ESG criteria into investment analysis and ownership practices in South Africa are listed in Appendix A. The most important of these 
occurred in 2011 and include amendments to Regulation 28 of the Pension Funds Act (No. 24 of 1956) and the launch of the launch of CRISA. All the interviewees saw the amendments to Regulation 28 as an essential first step in developing RI in South Africa. One participant commented that this development represents a 'significant game changer'.

To summarise, most of the RI funds available to transformation-orientated investors in South Africa employ an impact investing strategy focusing on infrastructure development and economic empowerment. Although impact investments offer diversification benefits (given a low level of correlation with listed securities), they are plagued by liquidity concerns and the lack of market valuations.

\section{CONCLUSIONS AND RECOMMENDATIONS}

The purpose of this article was to investigate the RI strategies and criteria used by South African fund managers over the 21 years since the launch of the first RI fund in the country in 1992 . The findings suggest that the market has seen limited growth, both in the number of funds and the assets under management. A strong preference for impact investing and social criteria was observed, and although these are appropriate in an emerging market context, a broader range of strategies and criteria needs to be adopted if $\mathrm{Rl}$ is to reach its full potential.

Asset managers could capitalise on gaps in the current RI offering by creating RI-orientated property funds, dedicated green funds and funds which employ a best-in-sector screening strategy.

In 2002, De Cleene and Sonnenberg (2002:52) already noted a social bias in the investment criteria employed by local Rl asset managers. They suggested the inclusion of more environmental screens, focusing on alternative technologies, waste minimisation and land biodiversity. Their suggestion is still valid today, and represents diversification opportunities for asset managers.

It is further suggested that more attention be given to water-related considerations, whether as screens, engagement themes or as the focus of impact investments. This recommendation is particularly relevant given predictions that three of the country's economic hubs (Johannesburg, Cape Town and Durban) will face severe water shortages by the year 2025 (De Villiers \& De Wit, 2010:1). It is estimated that the demand for water in these cities will exceed availability by a factor of about two. South Africa's current economic investment in low-carbon and associated infrastructure is also too low to remain economically competitive (World Wildlife Fund, 2012a,b). Environmental issues highlighted as deserving of more attention in South Africa include:

- the destruction of natural habitats owing to proposed economic activity;

- the protection of freshwater resources in the interests of water security;

- overfishing and overharvesting of many commercially valuable species and products; and

- water pollution.

Regulatory changes and voluntary initiatives such the UNPRI and CRISA call for focused education and training programmes as well as more and better quality ESG research and data. These developments represent several opportunities for consultants, research houses and higher education institutions. As far as could be established, only one dedicated module on RI was 
presented at a South African business school at the end of 2012. The training provided by the Sustainable Returns for Pensions and Society Project (2013) in the pension fund industry is commendable in that it provides practical RI tools (Kirima, 2012:80). The project's focus on capacity building could serve as a model for other educators in the field. More details on this national RI training initiative are presented in APPENDIX A.

Interviewees had very specific suggestions and requirements regarding future academic research. These included the identification of material ESG criteria in specific industries and clarification on the financial performance of RI funds. Greater insight into the role of trade unions in promoting RI in South Africa is also required, as well as case studies on successful shareholder engagements and impact investments. Research could also be undertaken to determine the appropriateness of Shari'ah-compliant funds for investors from other religions.

In 2004 a market analyst remarked that RI in South Africa is "a big boat we are still trying to row with little oars ... and we have a long way to go before we reach the harbour gates and high seas" (Finlay, 2004). Given a number of positive developments over the past decade, it could be argued that RI in South Africa has finally reached the harbour gates, although a number of challenges still remain for the movement to reach maturity. The findings of this study, however, suggest that there is a greater willingness among market participants than before to address these challenges and thus meet the needs of both self-referential and transformationorientated RI investors in South Africa.

\section{Acknowledgement}

The author would like to express her sincere gratitude to all the stakeholders in the RI field who have, over the years, assisted her in conducting research on the topic. She would also like to thank Professors Johan Bosch, Eon Smit and Colin Firer for their guidance and support.

\section{LIST OF REFERENCES}

Abdulla, F., Hassan, T. \& Mohamad, S. (2007). Investigation of the performance of Malaysian Islamic unit trust funds: comparison with conventional unit trust funds. Managerial Finance, 33(2), pp. 142153.

Abegbite, \&. \& Amaeshi, K. \& Amao, 0. (2012). The politics of shareholder activism in Nigeria. Journa/ of Business Ethics, 105(3), pp. 389-402.

Albanese, C. (2012). Focus on emerging markets - Sharia-compliant funds offer safe-haven. InvestmentEurope, 20 July, [Online] Available: http://www.investmenteurope.net/investmenteurope/news/2191314/focus-on-emerging-markets-shariacompliant-funds-offer-safehaven-involatile-markets. (Accessed 14 January 2012).

Ambachtsheer, J., Myllynen, J. \& Nuzum, R. (2006). Perspectives on responsible investing - a survey of US pension plans, foundations and endowments and other long-tern savings pools. Mercer Investment Consulting. January, [Online] Available: http:///www.mercerlC.com. (Accessed 22 September 2006). 
Asian financial crisis. (2013). Investopedia. [Online] Available:

http://www.investopedia.com/terms/a/asian-financial-crisis.asp\#axzz2KDOlqiDH. (Accessed l May 2013).

Barnea, A., Heinkel, R. \& Kraus, A. (2005). Green investors and corporate investment. Structural Change and Economic Dynamics, 16(3), pp. 332-346.

Baue, W. (2002). South African fund applies socially responsible investing principles. SocialFunds, 13 May, [Online] Available: http://www.socialfunds.com/news/article.cgi/84l.html. (Accessed 1 June 2002).

Bauer, R., Otten, R. \& Rad, A.T. (2006). Ethical investing in Australia: is there a financial penalty? Pacific-Basin Financial Journal, 14(1), pp. 33-48.

Becht, M., Franks, J., Mayer, C. \& Rossi, S. (2010). Returns to shareholder activism: evidence from a clinical study of the Hermes UK Focus Fund. The Review of Financial Studies, 23(3), pp. 3093-3129.

Bell, G. (2004). Islam is spreading among black South Africans, Independent Online, 14 November, [Online] Available: http://www.iol.co.za/news/south-africa/islam-is-spreading-among-blacksouth-africans-1.226939. (Accessed 5 May 2013).

Bhana, N. (2010). The stock market reaction to criticism of corporate governance practices of companies listed on the JSE. Investment Analysts Journal, 72, pp. 1-11.

Bridge, S. (1999). Empowerment finance deals come of age. Business Times, 14 March, [Online] Available: http://www.btimes.co.za/99/0314/comp/comp18.htm. (Accessed 14 March 1999).

Cameron, B. (2011). Revisions to regulation 28. Personal Finance, 25 July, [Online] Available: http://www.iol.co.za/business/personal-finance/financial-planning/investments/revisions-toregulation-28-1.1105151. (Accessed 25 July 2011).

Cameron, B. (2006). State pension fund to turn up heat on corporate SA. Personal Finance, 26 May, [Online] Available: http://www.persfin.co.za/index.php?fSectionld=595\&fArticleld=3264739. (Accessed 5 May 2013).

Cameron, J. (2003). Trust fund attracting Muslim money. Citizen, 18 September, p. 21.

Capelle-Blancard, G. \& Monjon, S. (2012). Trends in the literature on socially responsible investment: looking for the keys under the lamppost. Business ethics: a European review, 21(3), pp. 239-250.

Cape Town Green Week. (2009). Cape Town Partnership, 19 October, [Online] Available: http://www.capetownpartnership.co.za/cape-town-green-week/ (Accessed 15 May 2013).

Classification of South African regulated collective investment portfolios. (2012). Association for Savings and Investments SA. [Online] Available: http://www.asisa.org.za/index.php/collectiveinvestment-schemes/facts-on-collective-investment-portfolios/114-classification-of-southafrican-regulated-collective-investment-portfolios.html. (Accessed l April 2013).

Code for Responsible Investing by Institutional Investors in South Africa. (2013). Association of Savings and Investments SA. [Online] Available: http://www.asisa.org.za/index.php/infocentre/responsible-investment.html (Accessed 15 May 2013).

COP17/CMP7 - The Durban conference delivers a historical breakthrough in climate change talks. (2011). South African Government Information, December, [Online] Available: http://www.info.gov.za/speech/DynamicAction?pageid=461\&sid=23978\&tid=51896 (Accessed 15 May 2013). 
Cranston, S. (2012). Responsible investing. Financia/ Mail, 29 August, [Online] Available: http://www.fm.co.za/fm/2012/08/29/responsible-investing (Accessed 29 August 2012).

Crotty, A. (2012). SA shareholders slow to act on governance. Business Report, 8 May, [Online] Available: http://www.elementim.co.za/element-in-the-news/read/207/ (Accessed 8 May 2012).

Crotty, A. (2011). Ignore CRISA at your own risk. Business Report, 20 July, [Online] Available: http://www.iol.co.za/business/business-news/ignore-crisa-at-your-own-risk-1.1102150 (Accessed 15 May 2013).

David, P., Bloom, M. \& Hillman, A. (2007). Investor activism, managerial responsiveness and corporate social performance. Strategic Management Journal, 28, pp. 91-100.

De Cleene, S. \& Sonnenberg, D. (2004). Socially responsible investment in South Africa. $2^{\text {nd }}$ edition. African Institute of Corporate Citizenship, Johannesburg.

De Cleene, S. \& Sonnenberg, D. (2002). Socially responsible investment in South Africa. African Institute of Corporate Citizenship, Johannesburg.

Derwall, J., Koedijk, K. \& Ter Horst, J. (2011). A tale of values-driven and profit-seeking social investors. Journal of Banking and Finance, 35(8), pp. 2137-2147.

De Villiers, S. \& De Wit, M. (2010). $\mathrm{H}_{2} \mathrm{O}-\mathrm{CO}_{2}$ - energy equations for South Africa-present status, future scenarios and proposed solutions. Africa Earth Observatory Network Report Series 2, University of Cape Town, Cape Town.

De Vries, I. \& De Villiers, C.J. (1997). Ethical investing by South African unit trust managers. Meditari Accountancy Research, 1, pp. 31-43.

Dynes, M. (2009). Johannesburg Stock Exchange supports African commodities; trading grows. World Finance, [Online] Available: http://www.worldfinance.com/inward-investment/middle-east-andafrica/johannesburg-stock-exchange-supports-african-commodities-trading-grows (Accessed 5 March 2013).

Eccles, N.S. \& Viviers, S. (2011). The origin and meanings of names describing investment practices that integrate a consideration of ESG issues in the academic literature. Journal of Business Ethics, 104(3), pp. 389-402.

Eccles, N., Nicholls, S. \& De Jongh, D. (2007). The state of responsible investment in South Africa. University of South Africa Centre for Corporate Citizenship, Johannesburg.

Elfakhani, S. \& Hassan, M.K. (2005). Comparative Performance of Islamic Versus Secular Mutual Funds. Middle East Studies, November, [Online] Available: http://www.middle-eaststudies.net/wp.../sidani-IslamicMutualFunds.pdf (Accessed 4 May 2013).

Financial Sector Charter. (2002). Financial Sector Charter Council. [Online] Available: http://www.fscharter.co.za/page.php?p_id=149 (Accessed 1 May 2013).

Finlay, A. (2004). Investing in social responsibility. South Africa.info, 20 August, [Online] Available: http://www.southafrica.info/doing_business/economy/development/socialindex.htm (Accessed 4 June 2006).

FTSE/JSE Africa Index Series - Specialist Indices - Shari'ah. (2013). JSE. [Online] Available: http://www.jse.co.za/Products/FTSE-JSE/SpecialistIndices/Shariah.aspx (Accessed 1 May 2013).

FTSE/JSE SRI index. (2013). JSE. [Online] Available: http://www.jse.co.za/About-Us/SRI/Criteria.aspx (Accessed 1 May 2013). 
Giamporcaro, S. \& Pretorius, L. (2012). Sustainable and responsible investment (SRI) in South Africa: a limited adoption of environmental criteria. Investment Analysts Journal, 75(1), pp. 1-19.

Gifford, E.J.M. (2010). Effective shareholder engagement: the factors that contribute to shareholder salience. Journal of Business Ethics, 92 (Supplement), pp. 79-97.

Girard, દ.C. \& Hassan, M.K. (2008). There is a cost to faith-based investing: evidence from FTSE Islamic Indices. The Journal of Investing, (17)4, pp. 112-121.

Guide to JSE Listing Requirements. (2002). Deloitte \& Touche, [Online] Available:

http://www.deloitte.com/assets/Dcom-

SouthAfrica/Local\%20Assets/Documents/JSE\%20Listings\%20Requirements.pdf (Accessed 2 May 2013).

Hamilton, S., Jo, H. \& Statman, M. (1993). Doing well while doing good? The investment performance of socially responsible mutual funds. Financial Analysts Journal, 49(6), pp. 62-66.

Heese, K. (2005). The development of socially responsible investment in South Africa: experience and evolution of SRI in global markets, Development Southern Africa, (22) 5, pp. 729-739.

Hirsch, A. (2005). Season of hope - Economic Reform under Mandela and Mbeki. University of KwaZulu-Natal Press/IDRC. [Online] Available: http://www.idrc.ca/en/ev-91107-201-1D0_TOPIC.html (Accessed 5 October 2006).

Hirt, G.A., Block, S.B. \& Basu, S. (2006). Investment planning for financial professiona/s. McGraw-Hill: New York.

International Religious Freedom Report 2005. (2005). US Bureau of Democracy, Human Rights and Labor. [Online] Available: http://www.state.gov/j/drl/rls/irf/2005/51496.htm (Accessed 3 May 2013).

Islamic Wealth Management Report. (2012). Bank Sarasin: Switzerland.

Itano, N. (2002). In South Africa, many blacks convert to Islam. The Christian Science Monitor, 10 January, [Online] Available: http://www.csmonitor.com/2002/0110/p13sl-woaf.html (Accessed 3 May 2013).

Jackson, H. (2012). A way to catalyse funding to tackle high unemployment. Business Day, 11 December. [Online] Available: http://www.bdlive.co.za/opinion/2012/12/11/a-way-to-catalysefunding-to-tackle-high-unemployment (Accessed 11 December 2012).

Jenvey. N. (2003). Islamic bank thrives in tumultuous times. Business Day, 4 March, [Online] Available: http://allafrica.com/stories/200304040018.html (Accessed 4 March 2003).

Johannesburg Declaration on Sustainable Development. (2002). United Nations, 4 September, [Online] Available: http://www.un-documents.net/jburgdec.htm (Accessed 2 May 2013).

Judge, W.Q., Guar, A. \& Muller-Kahle, M.I. (2010). Antecedents of shareholder activism in target firms: evidence from a multi-country study. Corporate Governance: An International Review, 18(4), pp. 258273.

Kempf, A. \& Osthoff, P. (2007). The effect of socially responsible investing on portfolio performance. European Financial Management, 13(5), pp. 908-922.

King II empowers shareholders. (2002). Fin24, 26 March, [Online] Available: http://www.fin24.com/Companies/King-II-empowers-shareholders-20020326 (Accessed l April 2013). 
Kirima, W. (2012). Responsible investing toolkit for retirement fund trustees. COVER, June:, p. 80.

Larmer, R. (1997). The ethics of investing: a reply to William Irvine. Journal of Business Ethics, 16(1), pp. 397-400.

Leeman, M. (2005). Sifting through socially responsible investment jargon. Business Report, 8

February, p. 9.

Mills, P. (1996). Investing as a Christian: reaping where you have not sown? Cambridge Papers, 5(2), pp. 1-4.

Mr Stals discusses the impact of the international financial crisis on the South African economy.

(1999). Bank for International Settlements, 17 May. [Online] Available:

http://www.bis.org/review/r990519a.pdf (Accessed 7 December 2012).

Needham, C. (2004). Responsible funds make inroads. Sunday Times Business Times, 26 September, p. 13.

Neubaum, D.0. \& Zahra, S.A. (2006). Institutional ownership and corporate social performance: the moderating effects of investment horizon, activism and coordination. Journal of Management, 32(1), pp. 108-131.

New Growth Path. (2009). [Online] Available:

www.poa.gov.za/Outcome4/.../New\%20Growth\%20Path.pdf (Accessed 6 May 2013).

Nordén, L. \& Strand, T. (2011). Shareholder activism among portfolio managers: rational decision or 15 minutes of fame? Journal of Management Governance, 15, pp. 375-391.

Opportunities for impact investing in South Africa. (2009). South African Impact Investing Network. [Online] Available: http://www.greatergoodsa.co.za/files/SAIIN-A4-FINAL.pdf (Accessed l December 2012).

Patel, દ. (2012). Special Report - Islamic Finance 1. Accountancy SA. [Online] Available: http://www.accountancysa.org.za/resources/ShowltemArticle.asp?Articleld $=1446 \&$ lssue $=1010$ (Accessed 2 May 2013).

Peacock, B. (2011). Pension funds: new rules change investment allocations. Sunday times, 23 April, [Online] Available: http://www.timeslive.co.za/sundaytimes/article103471l.ece/pension-funds-new-rules-change-investment-allocations (Accessed 6 May 2013).

Pickworth, દ. (2012). Pension funds 'missing out on private equity'. Business day, 11 September, [Online] Available: http://www.bdlive.co.za/business/financial/2012/09/11/pension-fundsmissing-out-on-private-equity (Accessed 11 September 2012).

Planting, S. (2012). We need more capitalist activists - Theo Botha. Moneyweb, 29 February, [Online] Available: http://www.moneyweb.co.za/moneyweb-corporate-governance/we-need-morecapitalist-activists--theo-botha (Accessed 29 February 2012).

Poulsen, T., Strand, T. \& Thomsen, S. (2010). Voting power and shareholder activism: a study of Swedish shareholder meetings. Corporate Governance: An International Review, 18(4), pp. 329-343.

Proffitt, W.T. (Jr) \& Spicer, A. (2006). Shaping the shareholder activism agenda: institutional investors and global social issues. Strategic Organisation, 4(2), pp. 165-190.

Rademeyer, C. \& Holtzhausen, J. (2004). King II, corporate governance and shareholder activism. South African Law Journal, 120(4), pp. 767-775. 
Rakotamavo, M.T.J. (2011). Preferences of retail investors and institutions for corporate social performance. Journal of Sustainable Finance and Investment, 1(2), pp. 93-102.

Reconstruction and Development Programme. (1996). [Online] Available:

http://www.nelsonmandela.org/omalley/index.php/site/q/03lv02039/04lv02103/05lv02120/06lv021 26.htm (Accessed 7 December 2102).

Rehbein, K., Waddock, S. \& Graves, S.B. (2006). Understanding shareholder activism: which corporations are targeted? Business and Society, 43(3), pp. 239-267.

Renneboog, L., Ter Horst, J. \& Zhang, C. (2011). Is ethical money financially smart? Nonfinancial attributes and money flows of socially responsible investment funds. Journal of Financial Intermediation, 20, pp. 562-588.

Renneboog, L., Ter Horst, J. \& Zhang, C. (2008). Socially responsible investments: institutional aspects, performance, and investor behaviour. Journal of Banking and Finance, 32, pp. 1723-1742.

Responsible investing - global trends and local experience. (2012). National Business Initiative, 23 July, [Online] Available:

http://www.nbi.org.za/Lists/Publications/Attachments/254/NBI\%20Responsible\%20Investment\%20 -\%20Paul\%20Simpson,\%20CE0\%20CDP\%20London\%2023\%20)uly\%202012.pdf (Accessed 7 May 2013).

Richardson, B.J. \& Cragg, W. (2010). Being virtuous and prosperous: SRI's conflicting goals. Journal of Business Ethics, 92 (Supplement), pp. 21-39.

Rise in Shari'ah compliance. (2012). Voice of the Cape, 8 October, [Online] Available:

http://www.vocfm.co.za/index.php?option=com_k2\&view=item\&id=6595:rise-in-Shari'ahcompliance\&ltemid=153 (Accessed 8 0ctober 2012).

Sadasivaiah, S., Tozan, Y. \& Breman, J.G. (2007). Dichlorodiphenyltrichloroethane (DDT) for indoor residual spraying in Africa: how can it be used for malaria control? The American Journal of Tropical Medicine and Hygiene, 77(6 Supplement), pp. 249-263.

Schwartz, M.S., Tamari, M. \& Schwab, D. (2007). Ethical Investing from a Jewish Perspective. Business and Society Review, 112(1), pp. 137-161.

Sharia. (2013). Wikipedia. [Online] Available: http://en.wikipedia.org/wiki/Sharia (Accessed l May 2013).

Shari'ah compliant funds. (2013). Investopedia. [Online] Available:

http://www.investopedia.com/terms/s/shariah-compliant-funds.asp\#axzz2)vidyOSP (Accessed l May 2013).

Sinclair, G. \& Yao, R. (2011) Sustainable Investment in Sub-Saharan Africa - investment practitioner views on sustainable investment in private equity and asset management in South Africa, Nigeria and Kenya. [Online] Available:

http://www.ifc.org/ifcext/sustainability.nsf/Content/Publications_Report_SISubSaharanAfrica (Accessed 29 January 2012).

Sjöström, દ. (2008). Shareholder activism for corporate social responsibility: What do we know? Sustainable Development, 16(3), pp. 141-154.

Sosa, S. (2010). Creating a new asset class for social entrepreneurs. Inc. 12 0ctober, [Online] Available: http://www.inc.com/article/2010/10/creating-a-new-asset-class-for-socialentrepreneurs.html (Accessed l December 2010). 
South African business - Shifting the focus to performance. (2012). Carbon Disclosure Project, [Online] Available https://www.cdproject.net/CDPResults/CDP-South-Africa-Climate-ChangeReport-2012-Summary.pdf (Accessed 19 January 2012).

South African Network for Impact Investing. 2013. [Online] Available: http://www.saiin.co.za/sample-page/ (Accessed 5 March 2013)

Sparkes, R. \& Cowton, C.J. (2004). The maturing of socially responsible investments: a review of the developing link with corporate social responsibility. Journal of Business Ethics, 52(1), pp. 45-57.

Statman, M. \& Glushkov, D. (2009). The wages of social responsibility. Financial Analyst Journal, 65(4), pp. 33-46.

Sustainable Returns for Pensions and Society Project. (2013). [Online] Available: http://www.sincosinco.com/resources/2012_Sustainable_Returns_Project_factsheet.pdf

Swart, R. (2011). Could Regulation 28 drive retirement fund consolidation? Moneyweb, 12 December, [Online] Available: http://www.moneyweb.co.za/moneyweb-wealth-building/could-regulation-28drive-retirement-fund-consolid?sn=2009\%20Detail (Accessed 12 December 2011).

Teoh, S.W., Welch, I. \& Wazzan, C.P. (1999). The effect of socially activist investment policies on the financial markets: Evidence from the South African boycott. Journal of Business, 72(1), pp. 35-89.

The King Report on Corporate Governance. (1994). Institute of Directors in Southern Africa, Johannesburg.

The King // Report on Corporate Governance. (2002). Institute of Directors in Southern Africa, Johannesburg.

The King I/I Report on Corporate Governance. (2009). Institute of Directors in Southern Africa, Johannesburg.

Thomas, S. (2004). Do good, do well. Financial Mail, 11 June, [Online] Available:

http://wwwfree.financialmail.co.za/report04/fundman204/afm.htm (Accessed 11 June 2004).

UNPRI. (2013). About the Pri Initiative. [Online] Available: http://www.unpri.org/About-Pri/AboutPri/ (Accessed 28 February 2013).

Van Beurden, P. \& Gössling, T. (2008). The worth of values - a literature review on the relation between corporate social and financial performance. Journal of Business Ethics, 82(2), pp. 407-242.

Viviers, S. \& Firer, C. (2013). Responsible investing in South Africa - a retail perspective. Journal of Economic and Financial Sciences, 6(1), pp. 217-242.

Viviers, S., Krüger, J. \& Venter, D.J.L. (2012). Ethical, environmental, social and corporate governance criteria - a South African perspective. African Journal of Business Ethics, 6(2), pp. 120-132.

Wadula, P. (2004). Advent of responsible business dawns in SA with introduction of new index. Business Day, 20 May, [Online] Available:

http://www.businessday.co.za/home.aspx?Page=BD4P1236\&amp;Menultem=BD4P1236 (Accessed 21 May 2004).

Weber, J. (2010). Impact investing' teeters on edge of explosive growth. New York Times, 90 ctober, [Online] Available: http://www.nytimes.com/2010/10/10/us/10bcweber.html?_r=l (Accessed l December 2010).

Wen, S. (2009). Institutional investor activism on socially responsible investment: $\varepsilon f f e c t s$ and expectations. Business Ethics: A European Review, 18(3), pp. 308-333. 
Williams, G. (2007). Some determinants of the socially responsible investment decision: A crosscountry study. Journal of Behavioural Finance, 8(1), pp. 43-57.

Winfield, J. (2011). The landscape of proxy voting at South African asset managers. RisCura, July, [Online] Available: http://www.riscura.com/docs/research/SpoiltVotesHigh_Aug2011.pdf (Accessed 1 April 2011).

World Wildlife Fund. (2012a). Living Planet Report. [Online] Available:

http://wwf.panda.org/about_our_earth/all_publications/living_planet_report/2012_lpr/ (Accessed 20 January 2013).

World Wildlife Fund. (2012b). Government's efforts to address key environmental issues welcomed but more needs to be done. [Online] Available:

http://www.wwf.org.za/what_we_do/climate_change/?uNewsID=5340 (Accessed 20 January 2013).

1997 Asian financial crisis. (2013). Wikipedia. [Online] Available:

http://en.wikipedia.org/wiki/1997_Asian_financial_crisis (Accessed l May 2013). 
APPENDIX A: KEY EVENTS SHAPING THE RI STRATEGIES AND CRITERIA USED BY SOUTH AFRICAN RI FUND MANAGERS OVER THE PERIOD 1 JUNE 1992 - 31 DECEMBER 2012

\begin{tabular}{|c|c|c|c|}
\hline Year & Keyevent & Brief description of the event & Impact of the event \\
\hline 1994 & $\begin{array}{l}\text { Publication of } \\
\text { the first King } \\
\text { Report on } \\
\text { corporate } \\
\text { governance in } \\
\text { South Africa } \\
\text { (King I) }\end{array}$ & $\begin{array}{l}\text { King I defined acceptable standards } \\
\text { of conduct for boards and directors } \\
\text { of JSE-listed companies, banks and } \\
\text { certain state-owned enterprises in } \\
\text { South Africa. The report strongly } \\
\text { advocated an integrated approach to } \\
\text { stakeholder management and set out } \\
\text { principles dealing with the } \\
\text { composition and mandate of a board } \\
\text { of directors (including the role of } \\
\text { non-executive directors and } \\
\text { categories of individuals who qualify } \\
\text { as non-executive directors), } \\
\text { appointments to the board, the } \\
\text { maximum term for executive } \\
\text { directors, determination and } \\
\text { disclosure of executive and non- } \\
\text { executive directors' remuneration, } \\
\text { board meeting frequency, balanced } \\
\text { annual reporting, requirements for } \\
\text { effective auditing, affirmative action } \\
\text { programmes and a company's code of } \\
\text { ethics (The King Report on Corporate } \\
\text { Governance, 1994). }\end{array}$ & $\begin{array}{l}\text { This report stressed the importance of } \\
\text { integrated stakeholder management } \\
\text { and the need for improved corporate } \\
\text { governance among JSE-listed } \\
\text { companies. The report provided asset } \\
\text { owners and managers with clarity on } \\
\text { measuring corporate governance } \\
\text { performance. }\end{array}$ \\
\hline 1996 & $\begin{array}{l}\text { Launch of the } \\
\text { Reconstruction } \\
\text { and } \\
\text { Development } \\
\text { Programme } \\
\text { (RDP) }\end{array}$ & $\begin{array}{l}\text { "The RDP, which was described as an } \\
\text { integrated, coherent socio-economic } \\
\text { policy framework, sought to mobilise } \\
\text { all the country's people and resources } \\
\text { to eradicate apartheid and build a } \\
\text { democratic, non-racial and non- } \\
\text { sexist future". Key programmes of the } \\
\text { RDP centred on meeting basic needs, } \\
\text { developing human resources, building } \\
\text { the economy and democratising the } \\
\text { state and society (Reconstruction } \\
\text { and Development Programme, 1996). }\end{array}$ & $\begin{array}{l}\text { The RDP specified the most important } \\
\text { social criteria in South Africa at the } \\
\text { time and highlighted opportunities in } \\
\text { the impact investment space. }\end{array}$ \\
\hline $1997 / 8$ & $\begin{array}{l}\text { The Asian } \\
\text { financial crisis }\end{array}$ & $\begin{array}{l}\text { The crisis, which started in 1997, } \\
\text { consisted of a series of currency } \\
\text { devaluations and other events that } \\
\text { spread through East Asian markets } \\
\text { such as Thailand, South Korea, Japan, } \\
\text { Indonesia, the Philippines and } \\
\text { Malaysia (Asian financial crisis, } \\
2013 \text { ). Financial markets across the } \\
\text { globe reacted sharply to the turmoil } \\
\text { that continued during the 3 and 4. } \\
\text { quarters of } 1997 \text { (1997 Asian } \\
\text { financial crisis, 2013). Although } \\
\text { South Africa did not experience the } \\
\text { same economic problems as the East }\end{array}$ & $\begin{array}{l}\text { Adverse economic conditions resulting } \\
\text { from the crisis severely depressed real } \\
\text { economic activity in South Africa and } \\
\text { led to the discontinuance of several } \\
\text { empowerment funds over the period } \\
2000 \text { to } 2003 \text {. Poor financial returns on } \\
\text { RI funds resulted in a very negative } \\
\text { attitude towards RI in general and } \\
\text { impact investments in particular. } \\
\text { Attention turned to Shari'ah-compliant } \\
\text { funds in the aftermath of the crisis. }\end{array}$ \\
\hline
\end{tabular}




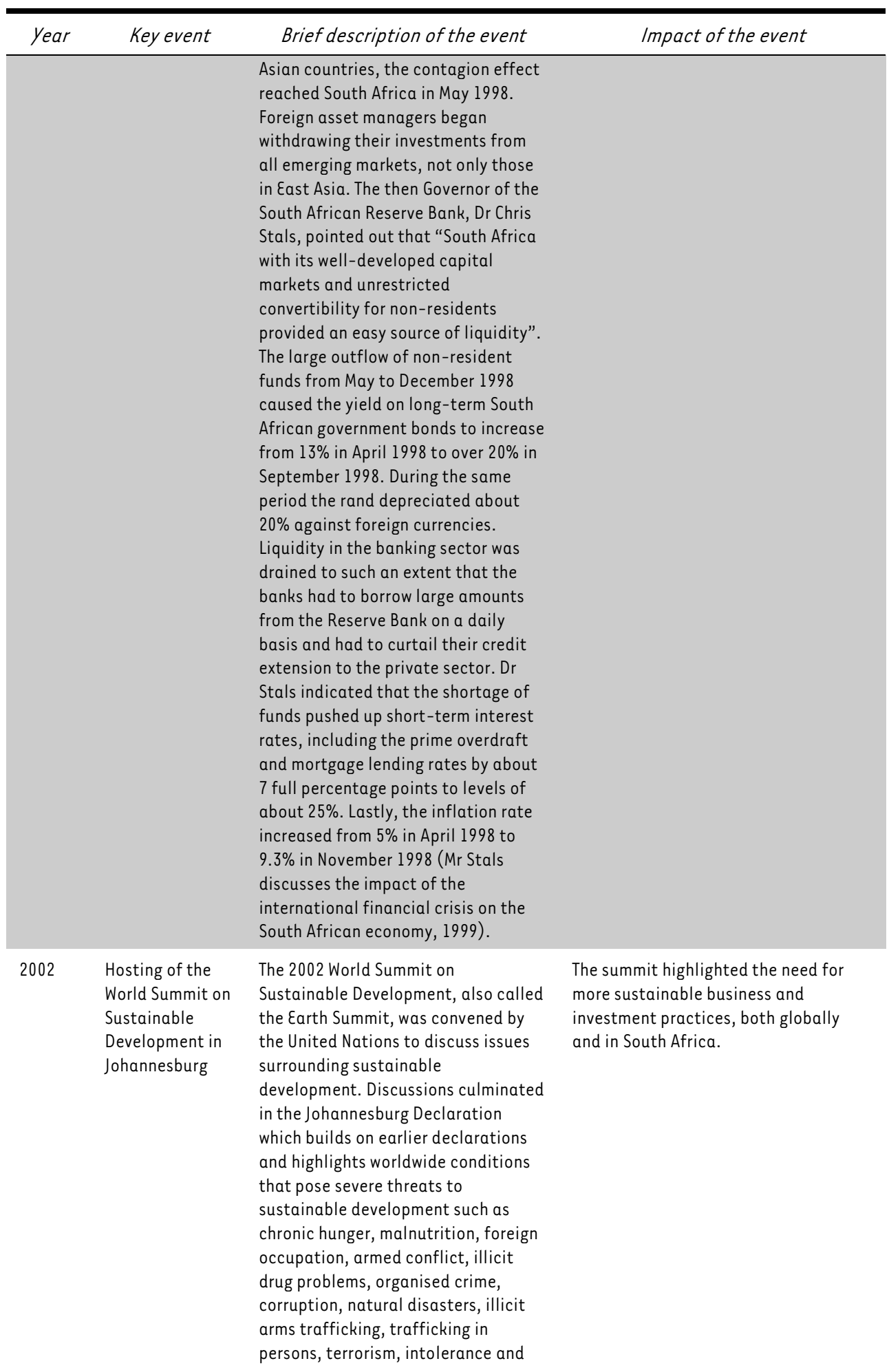




\begin{tabular}{|c|c|c|c|}
\hline year & Key event & Brief description of the event & Impact of the event \\
\hline & & $\begin{array}{l}\text { incitement to racial, ethnic, religious } \\
\text { and other hatreds, xenophobia and } \\
\text { endemic, communicable and chronic } \\
\text { diseases (in particular HIV/AIDS, } \\
\text { malaria and tuberculosis) } \\
\text { (Johannesburg Declaration on } \\
\text { Sustainable Development, 2002). }\end{array}$ & \\
\hline 2002 & $\begin{array}{l}\text { Publication of } \\
\text { the second King } \\
\text { report on } \\
\text { corporate } \\
\text { governance in } \\
\text { South Africa } \\
\text { (King II) }\end{array}$ & $\begin{array}{l}\text { In line with international } \\
\text { developments, King I was expanded } \\
\text { to include separate chapters on } \\
\text { sustainability, risk management and } \\
\text { the role of the board of directors (The } \\
\text { King II Report on Corporate } \\
\text { Governance, 2002). King II also } \\
\text { proposed a number of mechanisms, } \\
\text { including shareholder activism, to } \\
\text { ensure managerial conformance to } \\
\text { the principles of good governance. } \\
\text { After the publication of King II, all } \\
\text { JSE-listed entities were required to } \\
\text { disclose the extent of their } \\
\text { compliance with the report (Guide to } \\
\text { JSE Listing Requirements, 2002). Many } \\
\text { of the principles put forward in King II } \\
\text { were also embodied as law in the } \\
\text { Companies Act (No. } 71 \text { of 2008) (King } \\
\text { II empowers shareholders, 2002). }\end{array}$ & $\begin{array}{l}\text { This report emphasised the need for } \\
\text { sustainability and risk management. As } \\
\text { all JSE-listed entities were now } \\
\text { required to disclose the extent to which } \\
\text { they complied with King II, subsequent } \\
\text { improvements in corporate reporting } \\
\text { resulted (South African business - } \\
\text { Shifting the focus to performance, } \\
\text { 2012). King II provided additional } \\
\text { corporate governance criteria to be } \\
\text { considered and proposed shareholder } \\
\text { activism as a means of ensuring } \\
\text { managerial conformance to the } \\
\text { principles of good governance. }\end{array}$ \\
\hline 2004 & $\begin{array}{l}\text { Launch of the } \\
\text { Financial Sector } \\
\text { Charter }\end{array}$ & $\begin{array}{l}\text { The Charter resulted from on-going } \\
\text { discussions between the South } \\
\text { African government, business, labour } \\
\text { and community representatives. The } \\
\text { Charter set out to encourage } \\
\text { transformation in the financial } \\
\text { services sector in terms of the B-BBEE } \\
\text { Act and committed financial } \\
\text { institutions to transformation in the } \\
\text { areas of human resource } \\
\text { development, procurement of goods } \\
\text { and services, access to financial } \\
\text { services, ownership and control as } \\
\text { well as corporate social investment. } \\
\text { The Charter also encouraged the } \\
\text { provision of "empowerment financing } \\
\text { [including targeted investments in } \\
\text { transformational infrastructure, low- } \\
\text { income housing, agricultural } \\
\text { development and black SMEs as well } \\
\text { as BEE transaction financing]" } \\
\text { (Financial Sector Charter, 2002). }\end{array}$ & $\begin{array}{l}\text { The terminology and targets used in the } \\
\text { Charter, particularly as it pertained to } \\
\text { empowerment financing, provided } \\
\text { asset owners and managers with } \\
\text { greater clarity on the concept. }\end{array}$ \\
\hline 2004 & $\begin{array}{l}\text { Launch of the } \\
\text { FTSE/JSE Socially } \\
\text { Responsible } \\
\text { Investment }\end{array}$ & $\begin{array}{l}\text { As a means of focusing the debate on } \\
\text { triple bottom line performance } \\
\text { introduced by King II, the JSE } \\
\text { developed a set of criteria with which }\end{array}$ & $\begin{array}{l}\text { The names of companies included in } \\
\text { this index is publically available and } \\
\text { thus reduces the need for investors to } \\
\text { do independent ESG research which is }\end{array}$ \\
\hline
\end{tabular}




\begin{tabular}{|c|c|c|c|}
\hline year & Key event & Brief description of the event & Impact of the event \\
\hline & (SRI) index & $\begin{array}{l}\text { to measure the ESG performance of } \\
\text { companies included in the FTSE/JSE } \\
\text { All Share index. According to the JSE, } \\
\text { the SRI Index represents an } \\
\text { aspirational sustainability } \\
\text { benchmark, recognising listed } \\
\text { companies which incorporate } \\
\text { sustainability principles into their } \\
\text { everyday business practices. The } \\
\text { index also serves as a tool for } \\
\text { investors to assess companies on a } \\
\text { broader base (FTSE/JSE SRI index, } \\
2013 \text { ). }\end{array}$ & costly and time consuming. \\
\hline 2006 & $\begin{array}{l}\text { Launch of the } \\
\text { United Nations } \\
\text { Principles for } \\
\text { Responsible } \\
\text { Investment } \\
\text { (UNPRI) }\end{array}$ & $\begin{array}{l}\text { In } 2005 \text {, the former Secretary General } \\
\text { of the United Nations, Kofi Annan, } \\
\text { invited a group of the world's largest } \\
\text { institutional investors to develop the } \\
\text { UNPRI. Over the next year, intense } \\
\text { discussions took place between } \\
\text { investors from } 12 \text { countries and a } \\
\text { multi-stakeholder group of } 70 \\
\text { representatives from the global } \\
\text { investment industry, } \\
\text { intergovernmental organisations, } \\
\text { civil society and academia. This } \\
\text { process led to the formulation of six } \\
\text { principles which were launched in New } \\
\text { York in } 2006 \text { (UNPRI, } 2013 \text { ). By } \\
\text { becoming signatories, institutional } \\
\text { asset owners acknowledge that they } \\
\text { have a duty to act in the best long- } \\
\text { term interests of their beneficiaries } \\
\text { and that ESG issues can affect the } \\
\text { performance of investment portfolios } \\
\text { (to varying degrees across } \\
\text { companies, sectors, regions and } \\
\text { asset classes, and through time). } \\
\text { Signatories also recognise that } \\
\text { adherence to the Principles may } \\
\text { better align their objectives with } \\
\text { those of society. The Principles } \\
\text { commit signatories, which also } \\
\text { includes asset managers and advisory } \\
\text { service providers to: } \\
\text { - incorporate ESG issues into } \\
\text { investment analysis and } \\
\quad \text { decision-making processes; } \\
\text { be active owners and incorporate } \\
\text { - issues into ownership policies } \\
\text { - by the entities in which }\end{array}$ & $\begin{array}{l}\text { - The Principles provide signatories } \\
\text { with guidelines to align their } \\
\text { objectives with those of society. } \\
\text { Particular emphasis is placed on the } \\
\text { RI strategies of screening and } \\
\text { shareholder activism. The largest } \\
\text { pension fund in South Africa, the } \\
\text { Government Employees Pension } \\
\text { Fund (GEPF) was a founding } \\
\text { signatory of the Principles and } \\
\text { warned that they would use their } \\
\text { financial might to "force corporate } \\
\text { South Africa to shape up in areas of } \\
\text { good governance, social } \\
\text { responsibility and environmental } \\
\text { protection" (Cameron, 2006). As the } \\
\text { GEPF controls almost half of the } \\
\text { total retirement savings in the } \\
\text { country, they have the potential to } \\
\text { exert enormous influence on } \\
\text { corporate policies and practices. }\end{array}$ \\
\hline
\end{tabular}




\begin{tabular}{|c|c|c|c|}
\hline year & Key event & Brief description of the event & Impact of the event \\
\hline & & $\begin{array}{l}\text { they invest; } \\
\text { Promote acceptance and } \\
\text { implementation of the Principles } \\
\text { within the investment industry; } \\
\text { - Work together to enhance } \\
\text { effectiveness in implementing } \\
\text { the Principles; and } \\
\text { - Report on their activities and } \\
\text { progress towards implementing } \\
\text { the Principles. Possible actions: }\end{array}$ & \\
\hline 2007 & $\begin{array}{l}\text { Launch of the } \\
\text { FTSE/JSE } \\
\text { Shari'ah All } \\
\text { Share index }\end{array}$ & $\begin{array}{l}\text { The index tracks the performance of } \\
\text { Shari'ah-compliant companies that } \\
\text { are included in FTSE/JSE All Share } \\
\text { index thereby excluding companies } \\
\text { involved in conventional finance (e.g. } \\
\text { non-Islamic banking, finance and } \\
\text { insurance), alcohol, pork-related } \\
\text { products and non-Halaal food } \\
\text { production, packaging and } \\
\text { processing or any other activity } \\
\text { related to pork and non-Halaal food, } \\
\text { entertainment (casinos, gambling, } \\
\text { cinema, music, pornography and } \\
\text { hotels), tobacco, weapons, arms and } \\
\text { defence manufacturing (FTSE/JSE } \\
\text { Africa Index Series - Specialist } \\
\text { Indices - Shari'ah, 2013). }\end{array}$ & $\begin{array}{l}\text { As in the case of the FTSE/JSE SRI index, } \\
\text { the introduction of this index greatly } \\
\text { reduces the need for research on the } \\
\text { part of responsible investors. }\end{array}$ \\
\hline 2007 & $\begin{array}{l}\text { Introduction of } \\
\text { the Carbon } \\
\text { Disclosure } \\
\text { Project (CDP) in } \\
\text { South Africa }\end{array}$ & $\begin{array}{l}\text { Since } 2000 \text {, the CDP has challenged } \\
\text { the world's largest companies to } \\
\text { disclose their greenhouse gas } \\
\text { emissions, identify the perceived } \\
\text { risks and opportunities that climate } \\
\text { change present for their businesses } \\
\text { and describe their strategic } \\
\text { responses to these risks and } \\
\text { opportunities. The CDP has engaged } \\
\text { the JSE's largest } 100 \text { companies to do } \\
\text { the same from } 2007 \text { onwards. } \\
\text { According to the } 2012 \text { CDP South } \\
\text { Africa } 100 \text { Climate Change Report, the } \\
\text { top } 100 \text { are increasingly anticipating } \\
\text { and responding to climate change } \\
\text { issues. Not only did the number of } \\
\text { companies with greenhouse emissions } \\
\text { reduction targets increase in } 2012 \text {, } \\
\text { but improvements were also observed } \\
\text { in terms of disclosure, climate } \\
\text { change governance, risk management } \\
\text { and performance (South African } \\
\text { business - Shifting the focus to } \\
\text { performance, } 2012 \text { ). }\end{array}$ & $\begin{array}{l}\text { Access to detailed information on } \\
\text { greenhouse gas emissions and air } \\
\text { pollution among JSE-listed companies } \\
\text { makes it easier for investors to } \\
\text { evaluate the long-term strategic risks } \\
\text { to their portfolios. }\end{array}$ \\
\hline
\end{tabular}




\begin{tabular}{|c|c|c|c|}
\hline year & Key event & Brief description of the event & Impact of the event \\
\hline 2008 & $\begin{array}{l}\text { Launch of the } \\
\text { FTSE/JSE } \\
\text { Shar'iah Top } 40 \\
\text { index }\end{array}$ & $\begin{array}{l}\text { The index is essentially the same as } \\
\text { the FTSE/JSE Shar'iah All Share index, } \\
\text { but focuses on the } 40 \text { largest JSE- } \\
\text { listed companies. }\end{array}$ & $\begin{array}{l}\text { The existence of this index reduces the } \\
\text { need for research on the part of } \\
\text { responsible investors. }\end{array}$ \\
\hline $2008 / 9$ & $\begin{array}{l}\text { The global } \\
\text { financial crisis }\end{array}$ & $\begin{array}{l}\text { The crisis drove share prices on the } \\
\text { JSE to record lows in March } 2009 . \\
\text { However, within six months, and } \\
\text { despite the toughest market } \\
\text { conditions in living memory, the } \\
\text { FTSE/JSE All Share index bounced } \\
\text { back by } 50 \% \text { (Dynes, 2009). According } \\
\text { to some analysts, the JSE's resilience } \\
\text { confirmed that foreign investors were } \\
\text { returning to the market in ever larger } \\
\text { numbers. According to Sinclair and } \\
\text { Yao (2011), "there are now clear } \\
\text { indications that portfolio flows into } \\
\text { Africa as a whole are drifting } \\
\text { upwards, and expectations are } \\
\text { mounting that this will trigger a } \\
\text { renewed and sustained interest in } \\
\text { African listed securities". Private } \\
\text { equity investors are increasingly } \\
\text { seeing Africa as a new source of } \\
\text { growth (Dynes, 2009). }\end{array}$ & $\begin{array}{l}\text { Depressed financial market conditions } \\
\text { resulting from the crisis focus } \\
\text { attention on private equity (impact } \\
\text { investments) on the African continent. } \\
\text { Emphasis is placed on the } \\
\text { diversification benefits of these } \\
\text { investments. }\end{array}$ \\
\hline
\end{tabular}

\begin{tabular}{|c|c|c|c|}
\hline 2008 & $\begin{array}{l}\text { Launch of the } \\
\text { South African } \\
\text { Network for } \\
\text { Impact Investing }\end{array}$ & $\begin{array}{l}\text { The network was created by Greater } \\
\text { Capital, with founding support from } \\
\text { Cadiz Asset Management and Noah } \\
\text { Financial Innovation. The network's } \\
\text { conferences bring together investors, } \\
\text { social purpose businesses and } \\
\text { intermediaries to discuss } \\
\text { opportunities in the impact } \\
\text { investment space (South African } \\
\text { Network for Impact Investing, 2013). }\end{array}$ & $\begin{array}{l}\text { The creation of this network } \\
\text { highlighted the importance of impact } \\
\text { investing in the local RI market. The } \\
\text { network stimulates dialogue on the } \\
\text { concept, practice and growth of impact } \\
\text { investing in South Africa. }\end{array}$ \\
\hline 2009 & $\begin{array}{l}\text { Publication of } \\
\text { the third King } \\
\text { report on } \\
\text { corporate } \\
\text { governance in } \\
\text { South Africa } \\
\text { (King III) }\end{array}$ & $\begin{array}{l}\text { As indicated earlier, King II contained } \\
\text { a separate chapter on sustainability. } \\
\text { Not only was the focus on } \\
\text { sustainability increased in the third } \\
\text { King report on corporate governance } \\
\text { (King III), but the emphasis also } \\
\text { shifted to the notion of integrated } \\
\text { sustainability (The King III Report on } \\
\text { Corporate Governance, 2009). King III } \\
\text { incorporated four global emerging } \\
\text { governance trends, namely } \\
\text { alternative dispute resolution, risk- } \\
\text { based internal audit, shareholder } \\
\text { approval of non-executive directors' } \\
\text { remuneration and the evaluation of } \\
\text { the board and directors' } \\
\text { performance. New principles not }\end{array}$ & $\begin{array}{l}\text { The lack of adequate and measurable } \\
\text { information on companies' ESG } \\
\text { performance has long stifled the } \\
\text { adoption of RI strategies by } \\
\text { mainstream investors in South Africa. } \\
\text { King III's insistence on integrated } \\
\text { reporting has address this challenge } \\
\text { quite powerfully. }\end{array}$ \\
\hline
\end{tabular}




\begin{tabular}{|c|c|c|c|}
\hline year & Key event & Brief description of the event & Impact of the event \\
\hline & & $\begin{array}{l}\text { previously addressed dealt with IT } \\
\text { governance, business rescue and } \\
\text { directors' responsibilities during } \\
\text { mergers, acquisitions and } \\
\text { amalgamations. In contrast to the } \\
\text { earlier versions, King III is applicable } \\
\text { to all entities, public, private and } \\
\text { non-profit and recommends that } \\
\text { entities prepare an integrated report } \\
\text { (in line with the Global Reporting } \\
\text { Initiative's Sustainability Reporting } \\
\text { Guidelines) rather than a traditional } \\
\text { annual financial report and separate } \\
\text { sustainability report. In terms of the } \\
\text { JSE Listing Requirements, listed } \\
\text { companies are contractually bound } \\
\text { to adopt King III and any failure to do } \\
\text { so would amount to a breach of the } \\
\text { Listing Requirements. Management of } \\
\text { JSE-listed companies now need to } \\
\text { explain how the principles of the code } \\
\text { were applied, or if not applied, their } \\
\text { reasons for not applying them. }\end{array}$ & \\
\hline 2009 & $\begin{array}{l}\text { Launch of the } \\
\text { South African } \\
\text { government's } \\
\text { New Growth Path }\end{array}$ & $\begin{array}{l}\text { The plan emphasises infrastructure } \\
\text { development, job creation, } \\
\text { improvements to the agriculture } \\
\text { value chain and the creation of a } \\
\text { green economy. The principal target } \\
\text { of the plan is to create five million } \\
\text { jobs in the } 10 \text { years up to 2019. This } \\
\text { framework reflects government's } \\
\text { commitment to prioritising } \\
\text { employment creation in all economic } \\
\text { policies. It identifies strategies that } \\
\text { will enable South Africa to grow in a } \\
\text { more equitable and inclusive manner } \\
\text { while attaining South Africa's } \\
\text { developmental agenda (New Growth } \\
\text { Path, 2009). }\end{array}$ & $\begin{array}{l}\text { As in the case of the RDP, this plan } \\
\text { provides asset owners and managers } \\
\text { with clarity on material ESG issues and } \\
\text { opportunities in the impact investing } \\
\text { space. }\end{array}$ \\
\hline 2009 & $\begin{array}{l}\text { Hosting of the } \\
\text { United Nations } \\
\text { Environmental } \\
\text { Program Finance } \\
\text { Initiative (UNEP } \\
\mathrm{FI)} \mathrm{conference} \mathrm{in} \\
\text { Cape Town }\end{array}$ & $\begin{array}{l}\text { The UNEP FI is the largest and oldest } \\
\text { partnership between the United } \\
\text { Nations system and the world of } \\
\text { banking, insurance and investment. } \\
\text { Hundreds of financiers, investors, } \\
\text { business leaders, green groups and } \\
\text { built environment and property } \\
\text { professionals from around the world } \\
\text { and across Africa explored how a } \\
\text { green approach to business can } \\
\text { create jobs, protect the environment } \\
\text { and build better, fairer communities } \\
\text { with towns and cities that work (Cape } \\
\text { Town Green Week, 2009). }\end{array}$ & $\begin{array}{l}\text { The conference raised awareness } \\
\text { around environmental issues in general } \\
\text { and carbon emissions and green } \\
\text { construction in particular. }\end{array}$ \\
\hline
\end{tabular}




\begin{tabular}{|c|c|c|c|}
\hline year & Key event & Brief description of the event & Impact of the event \\
\hline 2011 & $\begin{array}{l}\text { Hosting of the } \\
\text { UN Convention } \\
\text { on Climate } \\
\text { Change (COP17/ } \\
\text { CMP7) in Durban }\end{array}$ & $\begin{array}{l}\text { Several important agreements were } \\
\text { reached at the convention, among } \\
\text { others the development of a green } \\
\text { climate fund to assist developing } \\
\text { countries in establishing their own } \\
\text { clean energy futures and adapting to } \\
\text { existing climate change. Along with } \\
\text { other developing countries, the South } \\
\text { African government adopted } \\
\text { procedures to allow carbon-capture } \\
\text { and storage projects in the country. } \\
\text { Governments furthermore agreed to a } \\
\text { significantly advanced framework for } \\
\text { the reporting of emission reductions, } \\
\text { taking into consideration the } \\
\text { common, but differentiated } \\
\text { responsibilities of different countries } \\
\text { (COP17/CMP7 - The Durban } \\
\text { conference delivers a historical } \\
\text { breakthrough in climate change } \\
\text { talks, 2011). }\end{array}$ & $\begin{array}{l}\text { The convention highlighted the need for } \\
\text { a more concerted effort to improve } \\
\text { environmental management and } \\
\text { reporting. As with the UNEP FI } \\
\text { conference, the emphasis was placed } \\
\text { on specific environmental criteria, } \\
\text { notably carbon emissions. }\end{array}$ \\
\hline 2011 & $\begin{array}{l}\text { Amendments to } \\
\text { Regulation } 28 \text { of } \\
\text { the Pension } \\
\text { Funds Act (No. } \\
24 \text { of 1956) }\end{array}$ & $\begin{array}{l}\text { After many years of deliberation, } \\
\text { Regulation } 28 \text { of the Pension Funds } \\
\text { Act (No, } 24 \text { of 1956) was finally } \\
\text { amended to "ensure that savings } \\
\text { invested in South African retirement } \\
\text { funds were invested in a prudent } \\
\text { manner, safeguarding these funds' } \\
\text { assets while taking on acceptable } \\
\text { levels of risk" (Peacock, } 2011 \text { ). A new } \\
\text { preamble to Regulation } 28 \text { highlights } \\
\text { the fiduciary responsibility of } \\
\text { retirement fund trustees to invest } \\
\text { savings in a way that promotes the } \\
\text { long-term sustainability of the asset } \\
\text { values, taking into account ESG } \\
\text { consequences of the investments. The } \\
\text { preamble also promotes trustee } \\
\text { education and the monitoring (by } \\
\text { trustees) of compliance by the fund } \\
\text { and its service providers. }\end{array}$ & $\begin{array}{l}\text { The amendments have two important } \\
\text { implications in terms of the RI } \\
\text { strategies and criteria used by local } \\
\text { assets and fund managers. Firstly, } \\
\text { pension fund trustees are now required } \\
\text { to develop an investment policy } \\
\text { statement which must describe the } \\
\text { fund's approach to trustee education, } \\
\text { B-BBEE and ESG issues, outline how it } \\
\text { will match its assets to its liabilities, } \\
\text { describe its due diligence process on all } \\
\text { investments and explain how it will } \\
\text { monitor compliance by its service } \\
\text { providers and how it will ensure } \\
\text { understanding of the fund's changing } \\
\text { risk profile (Cameron, } 2011 \text { ). Swart } \\
\text { (2011) maintains that "Regulation } 28 \\
\text { has changed the face of the retirement } \\
\text { fund industry. In addition to } \\
\text { emphasising members' interests and } \\
\text { trustees' obligations, it compels } \\
\text { trustees to adopt a liability-based } \\
\text { approach to investing and to take a } \\
\text { long-term view". Secondly, the new } \\
\text { prudential limits set out in Regulation } \\
28 \text { ease prior restrictions on alternative } \\
\text { investments, including hedge funds and } \\
\text { unlisted equities. The easing on } \\
\text { unlisted equities was undertaken to } \\
\text { ensure that investment into this pro- } \\
\text { development funding channel is not } \\
\text { impeded. There is an overall limit of }\end{array}$ \\
\hline
\end{tabular}




\begin{tabular}{|c|c|c|c|}
\hline Year & Key event & Brief description of the event & Impact of the event \\
\hline & & & $\begin{array}{l}15 \% \text { of retirement fund assets in hedge } \\
\text { funds and private equity funds. } \\
\text { Investment in a single hedge fund or } \\
\text { private equity fund is restricted to } \\
2.5 \% \text {, but the limit is higher ( } 5 \% \text { of } \\
\text { retirement fund assets for each entity) } \\
\text { if the investment is through a fund of } \\
\text { funds. "By recognising hedge funds and } \\
\text { private equity as separate asset } \\
\text { classes, trustees are encouraged to } \\
\text { consider these options and structure } \\
\text { optimal investment combinations for } \\
\text { their members" (Swart, 2011). It is } \\
\text { widely argued that the inclusion of } \\
\text { private equity will provide trustees with } \\
\text { another avenue (other than listed } \\
\text { securities) to explore B-BBEE and ESG } \\
\text { factors when investing (Cameron, } \\
2011 \text { ), especially in light of the } \\
\text { relatively small number of companies } \\
\text { listed on the JSE. }\end{array}$ \\
\hline 2011 & $\begin{array}{l}\text { Launch of the } \\
\text { Code of } \\
\text { Responsible } \\
\text { Investment in } \\
\text { South Africa } \\
\text { (CRISA) }\end{array}$ & $\begin{array}{l}\text { In response to the King III, the UNPRI } \\
\text { and changes to the Companies Act } \\
\text { (No. } 71 \text { of 2008), the Institute of } \\
\text { Directors in Southern Africa convened } \\
\text { a committee to draft CRISA. The } \\
\text { initiative was endorsed by key role } \\
\text { players such as the Principal Officers } \\
\text { Association, the Association for } \\
\text { Savings and Investment South Africa, } \\
\text { the Financial Services Board and the } \\
\text { JSE. The Code was launched in July } \\
\text { 201l and is based on the following } \\
\text { principles: } \\
\text { - Institutional investors should } \\
\text { incorporate sustainability } \\
\text { considerations, including ESG, } \\
\text { into their investment analysis } \\
\text { and activities as part of the } \\
\text { delivery of superior risk- } \\
\text { adjusted returns to ultimate } \\
\text { beneficiaries; } \\
\text { Institutional investors should } \\
\text { demonstrate their acceptance } \\
\text { of ownership responsibilities in } \\
\text { their investment arrangements } \\
\text { and activities; } \\
\text { Where appropriate, institutional } \\
\text { investors should consider a } \\
\text { collaborative approach to } \\
\text { promote acceptance and } \\
\text { implementation of the principles } \\
\text { of CRISA and other codes and }\end{array}$ & $\begin{array}{l}\text { The Code formally encourages } \\
\text { institutional investors to integrate ESG } \\
\text { issues into their investment decisions } \\
\text { and ownership practices. The Code } \\
\text { applies to institutional investors as the } \\
\text { owners of assets as well as their service } \\
\text { providers (asset managers and } \\
\text { consultants) and encourages them to } \\
\text { adopt its principles and practise } \\
\text { recommendations on an 'apply or } \\
\text { explain' basis (Code for Responsible } \\
\text { Investing by Institutional Investors in } \\
\text { South Africa, 2013). With the launch of } \\
\text { CRISA, South Africa became the second } \\
\text { country in the world (after the United } \\
\text { Kingdom) to provide institutional } \\
\text { investors with guidance on responsible } \\
\text { investment practices. Although } \\
\text { compliance with the code is voluntary, } \\
\text { Finance Minister Pravin Gordhan has } \\
\text { hinted that more active involvement by } \\
\text { the government could be expected if } \\
\text { "this voluntary code to promote more } \\
\text { open and broadly beneficial investment } \\
\text { was ineffective" (Crotty, 2011). }\end{array}$ \\
\hline
\end{tabular}




\begin{tabular}{|c|c|c|c|}
\hline year & Keyevent & Brief description of the event & Impact of the event \\
\hline & & $\begin{array}{l}\text { standards applicable to } \\
\text { institutional investors; } \\
\text { Institutional investors should } \\
\text { recognise the circumstances and } \\
\text { relationships that hold a } \\
\text { potential for conflicts of } \\
\text { interest and should proactively } \\
\text { manage these when they occur; } \\
\text { and } \\
\text { Institutional investors should be } \\
\text { transparent about the content } \\
\text { of their policies, how the } \\
\text { policies are implemented and } \\
\text { how CRISA is applied to enable } \\
\text { stakeholders to make informed } \\
\text { assessments. }\end{array}$ & \\
\hline 2012 & $\begin{array}{l}\text { Launch of the } \\
\text { Sustainable } \\
\text { Returns for } \\
\text { Pensions and } \\
\text { Society Project }\end{array}$ & $\begin{array}{l}\text { The project is a southern African, } \\
\text { industry-led initiative to integrate } \\
\text { ESG considerations into mainstream } \\
\text { retirement investment practices. The } \\
\text { project, which is a partnership } \\
\text { between the Principal Officers } \\
\text { Association and the International } \\
\text { Finance Corporation, strives to build } \\
\text { capacity and develop tools to support } \\
\text { principal officers and trustees in } \\
\text { implementing the new requirements } \\
\text { of Regulation } 28 \text { (Sustainable } \\
\text { Returns for Pensions and Society } \\
\text { Project, 2013). }\end{array}$ & $\begin{array}{l}\text { This project will assist in educating } \\
\text { stakeholders in the local pension fund } \\
\text { industry about RI. }\end{array}$ \\
\hline
\end{tabular}


Viviers 